\title{
Elektronik Beşli Çark, Basamak Değeri Çizelgesi ve Dokunma Sayar'da Sayının Anlamları
}

\author{
TheAspects of Number in e-Pascaline, Place Value Chart \\ andTouchCounts
}

\begin{abstract}
Samet OKUMUŞ*
Öz: Bu çalışmada, sırasıyla Elektronik Beşli Çark, Basamak Değeri Çizelgesi ve Dokunma Sayar olarak Türkçeye çevrilen e-Pascaline, Place Value Chart ve Touch Counts programları, sayının ordinallik ve kardinallik anlamları bakımından incelenmiştir. Sayının kardinallik anlamı bir gruptaki nesne sayısının bir sayı ile ifade edilmesini içerirken ordinallik anlamı sayıların kendi aralarındaki büyüklügünü, konumunu, sırasını vs. ele alır. Ayrıca belirlenen teknolojik araçlarda sıfırın ve basamak değerinin gösterim biçimleri incelenmiștir. İnceleme sonucunda, sayının ordinalliğinin ve kardinalliğinin anlamlandırılmasının Dokunma Sayar'da temel bir odak nokta olduğu bulunmuştur. Buna karşın, Elektronik Beşli Çark aracında sayının ordinallik anlamı daha fazla vurgulanmı̧̧ken, Basamak Değeri Çizelgesinde ise sayının kardinallik anlamının ön planda olduğu gözlemlenmiştir. Ancak, kullanılma şekline bağlı olarak, bu iki araçta da sayının ordinallik ve kardinallik yönlerinin birlikte kullanılabileceği tartışılmıştır.
\end{abstract}

Anahtar Kelimeler: Basamak değeri çizelgesi, dokunma sayar, elektronik beşli çark, kardinallik, ordinallik

Abstract: In this paper, the ordinality and cardinality aspects of number in ePascaline, Place Value Chart and Touch Counts that are translated into the Turkish language as Elektronik Beşli Çark, Basamak Değeri Çizelgesi and Dokunma Sayar, respectively, are identified. While cardinality of number refers to the quantity of a group of objects, ordinality refers to the aspects of number in terms of relative magnitude, position, order etc. among numbers. Also, the selected digital artifacts are examined pertaining to the place value of numbers and how 0 (zero) is represented. Based upon the review, understanding the cardinality and ordinality aspects of number are found to be key focus areas in Touch Counts. The ordinality aspect of number is more emphasized in e-Pascaline, while the cardinality of the number is more foregrounded in Place Value Chart. However, it is discussed that both aspects of number may be used together in these artifacts, implementing tasks that enable students to reason about quantity and the sequence of numbers.

Keywords: Place Value Chart, Touch Counts, e-Pascaline, cardinality, ordinality

\section{Giriş}

Eski medeniyetlerden bu yana bir düşünme aracı olarak süregelen sayılar, çevremizi anlama, birçokluğu ifade etme, birtakım nesneleri karşılaştırma gibi gereksinimlerimizi karşılamada kullanılan en temel matematik ürünüdür (Argün, Arıkan, Bulut ve Halıcığlu, 2014). Bu anlamda, Argün ve diğerleri (2014) sayıları "sayma, etiketleme, sıralama, kodlama, ölçme v.b. eylemler için kullanılan matematiksel nesnelerdir” (s. 443) şeklinde tanımlamış ve soyut bir kavram olan sayıların sembolik gösterimleriyle kullanıldığını ifade etmiştir. Bir rakamla veya birden fazla rakamın bir araya gelmesiyle ifade edilen sayılar, anlamlandırma, kıyaslama gibi birçok durumu açıklamada önemli rol oynar. Bunun yanı sıra sayma kümelerle de ilişkilendirilebilir (Argün ve diğerleri, 2014; Demircioğlu, 2016). Yani, "sayma bir kümede kaç tane nesne olduğunu söylemektir" (Argün ve diğerleri, 2014, s. 446).

Tall'a (2013) göre sayıların ve aritmetiğin kavranmasına giden yol özellikle sayma becerisinden ve bu beceride kullanılan sayma stratejilerinden geçer. Sayı anlamının kavramsal olarak oluşturulmaya başlandığına işaret eden en önemli gösterge, bir nesne topluluğunun hangi sırada sayılırsa sayılsın aynı sayıyla sonlandığının fark edilmesidir (Tall, 2013). Bu anlamda, sıra-

\footnotetext{
* Dr. Öğr. Üyesi, RecepTayyipErdoğanÜniversitesi, EğitimFakültesi, Rize-Türkiye, ORCID: 0000-0001-5905-196X, e-posta: samet.okumus@erdogan.edu.tr
} 
bağımsızlık ilkesi (bkz. Alptekin, 2015) olarak da bilinen bu ilkede, sayılara ve aritmetiğe yüklenen anlamların belirlenmesi önemli olarak görülmektedir. Tall'ın (2013) vurguladığı gibi, "saymada bireysel nesneleri bir araya getirerek bir topluluk oluştururuz ve bu topluluğu sayarız" (s.97). Sayıların somut ve elle tutulabilir nesnelerle eşleştirilmesi, "sayının, nesnelerin çokluklarını ve miktarını belirten sayma/kardinal" (Baki, 2018, s. 217) anlamı ile açıklanabilir. Sayının kardinal anlamı her ne kadar sayının büyüklügü bakımından çocuklara fikir verse de basamak değerinin kavranması bakımından zorluk teşkil edebilir. Örneğin, Tall (2013) bir öğrencinin bireysel nesnelerin sayılmasına odaklanmasının bu öğrencinin on adet nesnenin bir onluk oluşturduğu fikrine geçiş yapmasını zorlaştırdığını ifade etmiştir (bkz. s. 91).Çocukların sayma işlemi yaparken sayıları parmaklarıyla eşleştirmesi oldukça sık karşılaşılan bir durumdur. Benzer şekilde, kardinal anlamda, çocuklar bu eşleştirmeyi somut materyallerle (abaküs vb.) veya teknolojik araçlarla (Touch Counts vb.) da yapabilmektedir (Bartolini Bussi ve diğerleri, 2018). Ancak, kardinal anlamın yanı sıra "sayının, nesnelerin kendi aralarındaki durumlarının belirten sıralama/ordinal" (Baki, 2018, s. 217) anlamı da artan bir ivme ile araştırılmaktadır (Sedaghatjou ve Campbell, 2017; Sinclair, 2018; Sinclair ve Zaskis, 2017).

Son yıllarda ilgili ulusal alanyazın incelendiğinde sayıların kardinallik ve ordinallik gibi farklı anlamına dair vurgulara rastlanmaktadır (Akkaya 2019; Baki, 2018; Demircioğlu 2016). Ancak, ulusal alanyazındaki çalışmalarda sayının kardinal anlamına ağırlık verildiği görülmektedir (bkz. Mutlu, Olkun ve Cumhur, 2019; Olkun, Fidan ve Babacan Ö̈zer, 2013). Bu anlamda, bu çalışma ile sayıların farklı anlamlarını kullanmaya yönelik bir farkındalık oluşturulması hedeflenmektedir. Ayrıca, öğrencilerin somut materyaller kullanarak sayma becerilerine yönelik çalışmalara rastlanırken (örn. Mutlu ve diğerleri, 2019), teknolojik araçlarla ilgili olan çalışmalara rastlanmamıştır. Bu çalışmada, matematik eğitimi alanında son yıllarda yurtdışı araştırmalarda sıklıkla kullanılan ve matematik eğitimcileri tarafından geliştirilmiş ePascaline, Place Value Chart ve Touch Counts isimli teknolojik araçlar sayının kardinallik ve ordinallik anlamlarına göre incelenmiştir.

Araştırmalar sayıların sözel ve sembolik olarak ifade edilmesinde ve anlamının kullanımında öğrenci zorluluklarına işaret etmiştir (bkz. Arslan ve Ubuz, 2015; Tall, 2013). Bu çalışmada güncel teknolojik araçların ordinallik/kardinallik bakımından tasvir edilmesiyle birlikte sayıların sözel ve sembolik olarak ifade edilmesinde eğitimcilere yol gösterici olabileceği düşünülmektedir. Ayrıca, çalışmaya dâhil edilen teknolojik araçların yanı sıra farklı teknolojik araçları araştırma veya öğretim amaçlı kullanmayı planlayan eğitimcilerin farklı değişkenleri (ordinallik vs.) göz önüne alabileceği öngörülmektedir.

\section{Sayının anlamlart}

Formel anlamda sayıların anlamının yanı sıra, araştırmalarda sayının kardinallik ve ordinallik anlamlarının daha ön planda olduğu söylenebilir (bkz. Bishop, Lamb, Philipp, Whitacre ve Schappelle, 2014; Colomé ve Noël, 2012). Sedaghatjou ve Campbell (2017) sayının ordinal ve kardinal anlamını çocukların kavrayabilmelerinin karmaşık bir bilişsel süreçten geçtiğini ifade etmiş, hafıza gelişimi ve kestirimde bulunma (anticipation) temel becerilerinin sayının ordinal ve kardinal anlamlarıyla sağlanabileceğini vurgulamıştır. Daha önce de ifade edildiği gibi, sayının kardinallik anlamı bir gruptaki nesne sayısının bir sayı ile ifade edilmesini içerir (bkz. Akkaya 2019; Baki, 2018; Bruce ve Threlfall, 2004; Fuson, 1988; Olkun ve diğerleri, 2013). Bruce ve Threlfall (2004) sayının kardinallik anlamının sayma (counting) ve saymadan anlık bilme yetisinin (subitizing) anlamlandırılmasıyla belirlenebileceğini ifade etmiştir. Bu anlamda sayma işleminde, bir toplulukla yer alan nesneler ardıl olarak sayılarla birebir eşlenmeli ve her nesne atlanmadan bir kez sayılmalıdır. Şipşak sayılama/sayma olarak da bilinen saymadan anlık bilme yetisi (bkz. Mutlu ve diğerleri, 2019; Olkun ve diğerleri, 2013) ise az say1daki bir grup nesneyi, sayılarla birebir eşleme yapmaksızın gruptaki nesnelerin sayısını belirlemeyi içerir. Sayının kardinallik yönünde ilişkili olan sayma ve saymadan anlık bilme yetisinin birbirinden bağımsız olduğu ifade edilmektedir (Fuson, 1998; Gelman ve Gallistel, 1978'den akt., Bruce ve Threlfall, 2004). 
Sayının ordinallik anlamı sayıların kendi aralarındaki büyüklüğünü, konumunu, sırasını, azlık veya çokluk durumlarını ele alır (Akkaya 2019; Baki, 2018; Fuson, 1988). Fuson (1988) ordinal durum (ordinal situation), sıra ilişkileri (order relations) ve sıralama (ordering) arasındaki farka dikkat çekmiştir. Ordinallik durumunda, bir sayının sıralamaya bağlı olarak bu sıralamadaki durumunu veya konumunu, birinci, ikinci gibi ifadelerle tasvir edilmesi söz konusudur. Sira ilişkilerinde ise birbirine eş olmayan ve halihazırda kardinallik, ordinallik, ölçüm gibi durumlar temel alınır. Örneğin, "10elma, 4elmadan daha fazladır" (Fuson, 1988) şeklinde verilen ifadede elmaların çokluğu sayılarla belirtildiğinden kardinallik anlamı vardır. Ancak, bu ifadede geçen sayılar kendi arasında bir azlık-çokluk (veya büyüklük-küçüklük) sıra ilişkisine tabii tutulmuştur. Diğer bir örnek ise bir "kitabın 4 numaralı sayfası" (Akkaya, 2019, s. 146) üzerinden yapılabilir. Bu ifadede, kitabın sayfalarının numaralandırıldığı ön plana çıkarılmış ve 4 numaralı sayfanın 3. ve 5. sayfalar arasında yer aldığı ima edilmiştir (Akkaya, 2019). Bu sebeple, "bir kitabın 4 numaralı sayfası" ifadesinde sıra ilişkileri gözlenmektedir. Son olarak, "verilen bir sonlu kümenin tüm elemanları üzerinde verilen bir sıralama ilişkisinin tekrarlı kullanımı sıralama ile sonuçlanır" (s. 14, italik orjinalde). Bir sıralamada özellikle ordinal anlamda bir sıra ilişkisinin yer alması gerekmektedir, aksi halde sayının sıralama durumundan bahsedilemez. Örneğin bir bilet kuyruğunda sıralanmış kaç kişinin olduğu sorusu, sayılar arasında doğrudan bir büyüklük/küçüklük, azlık/çokluk ilişkisine imkân vermemektedir. Benzer şekilde sayıların kendi aralarında göreceli konumları veya büyüklükleri bilgisine bu ifade ile erişilemeyeceğinden, verilen ifade sıralamaya bir örnek teşkil etmez (Fuson, 1988).

Ladel ve Kortenkamp $(2011,2014)$ birebir eşleme yapılarak elde edilen saymanın ordinallik anlamının olduğunu ifade eder, çünkü Şekil 1'de gösterildiği gibi sayılar arasındaki sıra ilişkisi kullanılır (örneğin 3 sayısı 2'den sonra, 4'ten önce söylenmiştir). Gruptaki tüm nesnelerin sayısını, en son söylenen sayı ile ifade etmek ise kardinallik ilkesi (bkz. Olkun ve diğerleri, 2013) ile açıklanabilir. Olkun ve Toluk'a (2003) göre çocuklar genellikle taklide dayalı sözel saymanın ardından düzenli saymaya geçer. Yani, küçük yaştaki çocuklar etraftan duymuş olduğu sayıları ezberleme ve tekrarlama girişiminde bulunurlar. Zamanla, ordinal anlamlar oluşmaya başlar. Örneğin, sözel saymada 2 ile 3 rakamları çocuk için farklı şeyleri ifade etmezken, sayının sıra değerinin kazanılmasıyla "çocuk 3 ün daima 2 den sonra, 4 ün de 3 den sonra geldiğini ve bunların daima böyle olduğunu anlaması ile sayıların bir düzeninin olduğunu farkına varmış olur" (s. 71). $\mathrm{Bu}$ dönemde, çocuğun sayı haznesi oldukça sınırlıdır. Sonrasında birebir eşleme ile sayının kardinal değerinin anlaşılması için zemin hazırlanır ve sayının korunumunun kavranmasına geçilir. Son olarak, sayılar arasında nicelik bakımından karşılaştırmalar yapılır (Olkun ve Toluk, 2003). Ancak, Colomé ve Noël (2012) okul öncesi dönemdeki çocuklar (3, 4, 5 yaşlar) üzerinde yaptıkları çalışmada, çocukların sayının kardinallik anlamını, ordinallik anlamına göre daha kolay edinebildiklerini gözlemlemiştir.
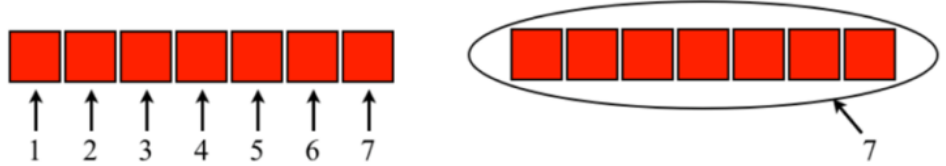

Şekil 1. Sayıların ordinal (solda) ve kardinal (sağda) anlamlarının gösterimi (Ladel ve Kortenkamp, 2011, s. 1)

Bu çalışmada her ne kadar sayıların kullanımlarına göre kardinal ve ordinal anlamları ön plana çıkarılmış olsa da sayının adlandırma, sembolik, ölçme gibi farklı anlamları da vardır (Akkaya 2019; Baki, 2018; Fuson, 1998). Adlandırma anlamında sayılar miktar, sıralama veya büyüklük gösterme amacı gütmeden bir nesneyi etiketlemede kullanılır. Baki'nin (2018) de ifade ettiği gibi "nesneleri tanımlamak için numaralandırmak nesneleri birbirinden ayırmak için etiketlendirmek sayının adlandırma/nominal anlamıdır" (s. 218). Sayının adlandırma anlamına telefon numaraları, araba plaka numaraları, alan kodları vs. örnek verilebilir (Baki, 2018; Fuson, 1988). Örneğin, adlandırma anlamında, "10 numaralı otobüsün üzerindeki 10 sembolü, binmek istediğimiz otobüsü bilmemizi sağlarken onu farklı sayılara sahip otobüslerin arasından ayırt 
edebilmemize da olanak sağlar" (Akkaya, 2019, s. 146). Sayının ölçüm anlamında, sürekli ölçüm birimleri (uzunluk, alan, hacim gibi) kullanılır ve ilgili nicelik sayı beraberinde seçilen uygun bir birimle ifade edilir. Bu anlamda, ölçek olarak kullanılan birim miktarına dayalı olarak herhangi bir sürekli niceliğe (continuous quantity) yönelik sayısal olarak açıklama getirilir (Fuson, 1988).

\section{Sayının sembollerle gösterimleri ve okunuşları}

Sayılara ifade ettiği çokluğa göre 1, 2, 3 gibi semboller atanıp bu ifadeler sözel olarak okunur (Baki, 2018). Bunun yanı sıra sayıların "saatin üzerindeki veya sayı doğrusu üzerindeki gibi analog ifadeleri de vardır" (s. 218). Sayıların ifade edilmesinde kuşkusuz ki sıfırın yazılı ve sözlü olarak ifade edilmesi önem taşımaktadır (Arslan ve Ubuz, 2015; Baki 2018; Olkun ve Toluk, 2003). Alanyazında sıfır rakamına farklı anlamların yüklendiği görülmektedir. Lakoff ve Núñez (1997) soyut olan sayıların somut nesneler, hareket gibi somut yapılarla açıklanabilmesi sebebiyle, sayıların ele alınış biçimlerini metaforik olarak değerlendirmiştir. $\mathrm{Bu}$ anlamda, sayıların birbirine eş nesneler topluluğu ve birimin en küçük nesne topluluğu olarak ele alındığ yaklaşımda sıfır, toplulukta hiçbir fiziksel nesne olmaması anlamına gelir. Sayıların fiziksel nesneler olarak düşünüldüğü ve birimin bütünün en küçük yapısı olarak ifade edildiği metaforik eşleştirmede ise benzer şekilde sıfır, hiçlik veya yokluk anlamına gelir. Son olarak, sayıların bir yörüngedeki (doğru gibi) dizilişlerine bağlı olarak sayıları konum bakımından ele alan metaforik eşleştirmede sıfır, orijin (başlangıç noktası) olarak kabul edilen yerdir. Birim ise orijinden bir adım (step) ilerleme üzerine kurulur.

Diğer yandan sıfır, bir yer tutucu olarak ifade edilmiştir (bkz. Arslan ve Ubuz, 2015; Olkun ve Toluk, 2003). Ancak, bunun öncesinde sayı ve basamak değerlerini ifade etmek gerekir. Örnek üzerinden verilecek olursa, 75 sayısının basamak değerleri $7 \times 10=70$ ve $5 \times 1=5$ iken, sayı değerleri 7 ve 5'tir. Yani, "bir sayıda rakamların bulundukları basamağa göre aldığ 1 değerlere basamak değeri ve rakamların sayı içinde bulundukları basamaklara bağlı olmadan aldıkları değere de sayı değeri" (Baki, 2018, s. 219) denir. Sayıların okunuşu basamak değerine göre gerçekleştirilir ve sıfır rakamı yazılı olarak bir sayıda tutulmasına rağmen ki yer tutuculuğu buradan gelir, sayının okunuşunda sıfır söylenmez. Örneğin, 30080 sayısı, okunurken sayı değerlerine göre "üç sıfır sıfır sekiz sıfır" şeklinde değil de basamak değerleri göz önüne alınarak "otuz bin seksen" şeklinde okunur (Arslan ve Ubuz, 2015). Alanyazında, sifirın yer tutucu olduğu sayıların okunmasında çocukların güçlük yaşadığı belirtilmektedir (bkz. Arslan ve Ubuz, 2015). Ross'a (2002) göre basamak değerinde toplanabilirlik (additive), konum (positional), on tabanı (base-ten) ve çarpımsal (multiplicative) olmak üzere toplamda dört özelliği anlamak önemlidir.

Toplanabilirlik özelliğinde bir sayının her bir basamağındaki değerlerinin toplanması ön plandadır. Örneğin, 302 sayısı 3 tane yüz ve 2 tane bir içermektedir. Bu sayı basamak değerlerinin toplanmasıyla oluşmakta ve soldan sağa olacak şekilde okunmaktadır. O halde 302 sayısı 300 ve 2 şeklinde parçalara ayrılmıştır. Konum özelliğinde, yazılı biçimde verilen bir sayıda yer alan rakamlar, diziliş sırasına göre bulunduğu basamaktaki değeri alır (iki yüzlük, beş onluk vs.). On tabanı özelliğinde, basamak değerleri sağdan sola gittikçe 10'un katları şeklinde arttı̆̆ vurgulanır. Son olarak, çarpımsal özelliğinde bir sayının bir basamağının değeri o basamakta bulunan rakam ile basamağa verilmiş değerin çarpımına eşittir. Örneğin, 302 sayısında yüzler basamağının değeri $3 \times 100=300$ 'dür. Coles ve Sinclair'e (2017) göre basamak değerinin ifade edilmesi kardinallik fikrini gerektirmez, daha ziyade sayıların okunma sırasını ve basamaklarını dikkate almayı gerektirir.

Dile bağlı olarak, sayıların okunuşları ile basamak değerlerine göre yazımları arasında uyumsuzluklar ortaya çıkabilmektedir (Ladel ve Kortenkamp, 2016a; Pimm, 2018). Örneğin, "dört ve yirmi" olarak okunan Alman dilindeki 24 sayısında ilk önce 4 rakamının söylenmesi sebebiyle birçok çocuk duydukları bu sayıyı 42 olarak yazmaktadır (bkz. Ladel ve Kortenkamp, 2016a). Olkun ve Toluk (2003) Türk dilinin ilk 19 sayısının ifade ediliş bakımından çocuklara fikir verdiğini belirtmiştir. Öyle ki ilk 10'a kadar saymayı sırasıyla bilen bir çocuk on bir, on iki gibi sayıların ifade ediliş biçimindeki ahengi yakalayabilmektedir. Ancak, 20 ve 20 'den sonra gelen onluklarda böyle bir ahenk yoktur. Örneğin 20 sayısının okunuşunu "iki on" şeklinde ifade etmediğimiz için yirmi çocuk için yeni bir kelimedir. Pimm (2018) benzer bir durumu İngiliz dili 
için ifade etmiştir. Örneğin, sırasıyla 11 ve 12 anlamına gelen "eleven" ve "twelve", on-bir (tenone) ve on-iki (ten-two) şeklinde parçalanarak okunmadığından çocuklar için 10'dan sonra gelen sayılar yeni kelimelerdir. 10'un, 90'a kadar olan katlarında (10 hariç) sayıların sonuna “-ty” eki getirilmesi (twenty, forty, fifty gibi) öğrencilere sayıların sıralanmasına dair ipuçları vermektedir (Coles ve Sinclair, 2017). Ancak, yine de 10'un katlarının okunuşları öğrenciler için birer yeni kelimedir.

\section{Yöntem}

Bu derleme çalışmasında sayının ordinallik ve kardinallik anlamları üzerine Elektronik Beşli Çark (e-BÇ), Basamak Değeri Çizelgesi (BDÇ) ve Dokunma Sayar (DS) programları değerlendirilmiştir. Bu teknolojik araçların seçimindeki temel ölçüt, yazılımların matematik eğitimcileri tarafından geliştirilmiş olmasıdır. Ayrıca, matematik eğitimi alanında uluslararası düzeyde prestijli bir konferans olan International Commission on Mathematical Instruction (ICMI) adlı konferansın 23. serisinde tamsayılar üzerine ilkokul matematiği ele alınmıştır. Bu konferansın bilimsel ürünlerinden biri de Bartolini Bussi ve diğerleri (2018) tarafından yazılmış olan bir kitap bölümüdür. $\mathrm{Bu}$ kitap bölümünde yazarlar öğrencilerin matematiksel bilgiyi oluşturmaları bakımından birçok teknolojik ve somut materyal hakkında bilgi vermiştir. $\mathrm{Bu}$ araştırmada değerlendirilen üç yazılımın (e-BÇ, BDÇ ve DS) belirlenmesinde Bartolini Bussi ve diğerleri (2018) tarafından yazılan kitap bölümü de referans alınmış ve belirlenen yazılımlar doküman analizine tabi tutulmuştur.

Her ne kadar eğitim araştırmalarında dokümanlar genellikle yazılı kaynak olarak düşünülse de yaygın inanışın aksine videolar veya yazılımlar gibi görsel/işitsel kaynaklar da doküman olarak değerlendirilmektedir (Yıldırım ve Şimşek, 2018). Yıldırım ve Şimşek'e (2018) göre doküman analizinin ilk aşamaları dokümanlara ulaşma ve ulaşılan dokümanların özgünlüğünü kontrol etmedir. Bu derleme çalışmasında Beşli Çark somut materyali ve Elektronik Beşli Çark yazılımı, Fransa'da düzenlenen bir konferans sırasında araçlarının geliştirilmesine katkı sağlayan Dr. Sophie Soury-Lavergne'den temin etmiştir. Bunun yanı sıra, Dokunma Sayar yazılımı ücretsiz olarak temin edilmişken Basamak Değeri Çizelgesi programı ise doğrudan satın alınmıştır. Doküman analizinde takip edilen bir diğer aşama ise dokümanları anlamadır (Yıldırım ve Şimşek, 2018). Bu bağlamda, yazılımları temin ettikten sonra araştırmacı yazılımların işleyiş mekanizmalarını yazılı belgeler (makale, bildiri, vs.) veya görsel/işitsel kaynaklar (You Tube videoları, yazılımların internet siteleri, vs.) yardımıyla incelemiştir. Teknolojik araçların ordinallik ve kardinallik anlamlarının incelenmesinde yazılımları geliştiren araştırmacıların (Dr. Nathalie Sinclair, Dr. Ulrich Kortenkamp, Dr. Sophie Soury-Lavergne, Dr. Michela Maschietto) yayınları özellikle referans alınmıştır. Bunun yanı sıra, araştırmacı yazılımların işleyiş mekanizması hakkında yeterince bilgi edindikten sonra, görev yaptığı kurumda ilköğretim matematik öğretmenliği programına verdiği seçmeli bir derste bu üç yazılımı öğretmen adaylarına tanıtmıştır. Doküman analizi bağlamında araştırmacının yazılımlarla ilgili deneyimleri dokümanı anlama bakımından araştırmaya katkı sağlamıştır.

Doküman analizinin son aşamalarını ise veri analizi ve veriyi kullanma oluşturur(Yıldırım ve Şimşek, 2018). Veri analizinde ilgili teknolojik araçlar ordinallik ve kardinallik anlamında tasvir edilmiştir. Bu bağlamda, toplama ve çıkarma işlemi ağırlıklı olarak etkinlik temelli gösterimler analiz birimi olarak ele alınmış ve yazılımlar ordinallik ve kardinallik bakımından değerlendirilmiştir. Sayının anlamları ile ilgili bulgular yazılımlardan alınan ekran görüntüleriyle desteklenmiştir. Yazılımların ordinallik ve kardinallik bakımından değerlendirilmesi sürecinde ele alınan bazı ölçütler şu şekildedir:

- Yazılımda temsil edilen sayılar görsel açıdan birçokluk veya konum/sıra belirtmekte midir?

- Yazılımda herhangi bir eylem gerçekleştirildiğinde kullanıcıya nasıl bir geri bildirim sağlanmaktadır? Verilen geri bildirimde çokluk veya konum/sıra ögelerine ne ölçüde rastlanmaktadır? 
- Yazılımda iki sayı toplandığında elde edilen sayı gruptaki nesne sayısı olarak temsil edilmekte midir?

- Yazılımda iki sayının toplanması sürecinde, yazılım sayıların birbirlerine göre konumunu veya sırasını ön plana çıkarmakta mıdır?

- İki sayının çıkarılması sürecinde gruptan nesne eksiltilmesi mi yoksa eksilen sayının konumunun değiştirilmesi mi ön plandadır?

\section{Çalışmada incelenen teknolojik araçlar}

Bu bölümde, ulusal alanyazında karşılaşılmaması sebebiyle e-Pascaline ${ }^{1}$, Place Value Chart $^{2}$ ve Touch Counts ${ }^{3}$ araçlarının kullanılma mekanizmaları hakkında bilgi verilmiştir. Matematik öğretim programlarında çocuklara sayıların anlamının erken yaşlarda kazandırılması hedeflendiği için, bu araçların kullanım mekanizmaları toplama ve çıkarma işlemi üzerinden örneklendirilmiştir. Çalışmanın özetinde de belirtildiği üzere, Place Value Chart programı Türkçe'ye "Basamak Değeri Çizelgesi”" olarak çevrilmişken, Touch Counts programı "Dokunma Sayar" olarak çevrilmiştir. Pascaline ve e-Pasca line ifadelerine doğrudan karşı gelebilecek Türkçe kelimeler bulunmamaktadır. Ancak, bu araçların işleyişleri göz önüne alınarak Pascaline "Beşli Çark" ve e-Pascaline "elektronik Beşli Çark" olarak isimlendirilmiştir.

\section{Elektronik beşli çark (e-Pascaline)}

Aritmetik Zero+1 makinesi (the arithmetical machine Zero+1) olarak da bilinen Pascaline somut materyali ismini Fransız bir matematikçi ve filozof olan Blaise Pascal'dan (1623-1662) almıştır (Bartolini Bussi ve diğerleri, 2018; Maschietto ve Soury-Lavergne, 2013a). Modern tasarımıla Beşli Çark (BÇ) aracı, Pascal tarafından geliştirilen mekanik aritmetik aracının çalışma prensibini içerir. Öyle ki sayılar ve basamaklar arasında harekete bağlı değişimler meydana gelir. Bu araçta birler, onlar ve yüzler basamakları birbirinden sarı çarklarla ayrılmış olup, en fazla üç basamaklı sayılarla çalışlabilmektedir. Basamaklar arasında eldeli işlemleri üst kısımda yer alan turuncu çarklar gerçekleştirir (Maschietto ve Soury-Lavergne, 2013a) (Şekil 2a). Bu bakımdan, turuncu çarklar yardımcı çark görevini üstlenir.

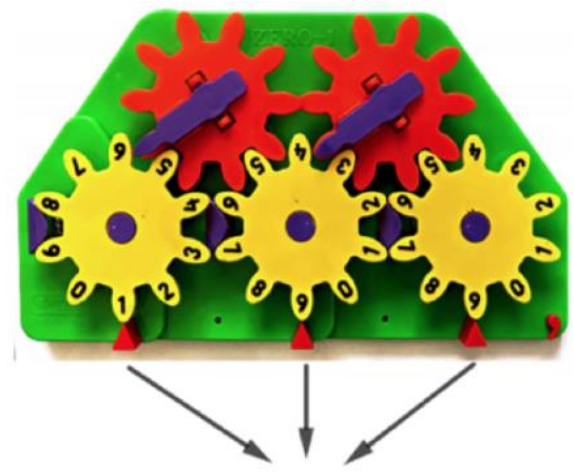

199

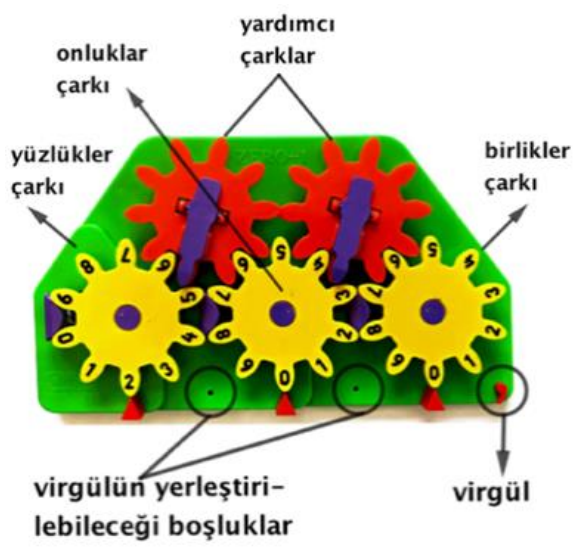

(b)

(a)

Şekil 2. (a) BÇ aracının göstergesindeki 199 sayısı, (b) BÇ'de 200 sayısının gösterimi

BÇ’nin çalışma mekanizmasını 199 sayısına 1 ekleme örneği üzerinden gösterilecek olunursa (bkz. Şekil 2a-b) öncelikle, birlik çarkındaki diş, el ile bir birim saat yönünde hareket ettirilir ve sonrasında 9 rakamının yerini 0 alır. Bu durumda onlar basamağına bir elde taşıma görevini üst kısımda yer alan turuncu çark (yardımcı çark) gerçekleştirir. Yani, yardımcı çark,

\footnotetext{
${ }^{1}$ e-Pascaline erişim adresi: http://educmath.ens-lyon.fr/Educmath/cabri-elem-ife/telechargement-deslogiciels-cabri-edition-ife

${ }^{2}$ Place Value Chart erişim adresi: https://appadvice.com/app/place-value-chart/568750442

${ }^{3}$ Touch Counts erişim adresi: https://apps.apple.com/us/app/touchcounts/id897302197
} 
onluk çarkındaki dişi bir birim saat yönünde hareket ettirerek 9 rakamını 0 yapar. Eş zamanlı olarak onlar basamağında da bir elde edildiğinden yüzler basamağını kontrol eden diğer turuncu yardımcı çark yüzlük çarkını bir birim saat yönünde çevirerek 1 rakamını 2 yapar. Bu durumda 199 sayısına 1 eklendiğinde 200'e ulaşıldığı görülür (Şekil 2b).

Sarı dişli çarklar el ile saat yönünün tersinde hareket ettirildiğinde ise çıkarma işlemi yapılmış olur. Benzer şekilde basamaklar arasındaki eldeli işlemleri turuncu yardımcı çarklar gerçekleştirir. Ayrıca, BÇ aracı virgülden sonra en fazla iki basamağa kadar ondalıklı sayılarda toplama ve çıkarma işlemleri yapmaya olanak verir. Bunun için Şekil 2b'de gösterildiği gibi BÇ üzerinde bulunan virgül alınarak istenilen boşluğa yerleştirilebilir. Böylece birler, onlar ve yüzler basamağını gösteren sarı çarkların temsil ettiği basamaklara yeni anlamlar yüklenmiş olur (onda birler ve/veya yüzde birler basamakları).

Fransa ve İtalya kurumlarından fon alan Malette isimli projelerinde, Maschietto ve SouryLavergne (2013a,b) BÇ aracının eşleniği olarak elektronik BÇ (kısaca e-BÇ) aracını geliştirmiştir. Ancak, bu iki araçlar birbirinin bire bir kopyası olmaktan ötürü birbirlerini tamamlar nitelikte olacak şekilde geliştirilmiştir. Bu anlamda, araçlar "a duo of artifact" yani bir "araç4 ikilisi”" olarak ifade edilmektedir. BÇ ve e-BÇ özellikle basamak değeri ve hesaplama yapma (toplama ve çıarma işlemi yapma) amaciyla geliştirilmiştir (Maschietto ve Soury-Lavergne, 2017). e-BÇ’nin yalnızca Fransızca versiyonunun piyasada olması sebebiyle, araştırmacılar çalışmalarını halen Fransız kurumlarında yürütmektedir (Maschietto ve Soury-Lavergne, 2013a). Araştırmacılar e$\mathrm{BÇ}$ aracının Android uygulamasını yakın zamanda piyasaya sürme hazırlıklarındadır. Ayrıca, somut materyal biçimiyle BÇ, İtalyan Quercetti ${ }^{5}$ firması aracılı̆̆ıyla üretilmekte ve firma birçok ülkede patent alma işlemlerini sürdürmektedir.

BÇ’ye benzer șekilde e-BÇ aracında da sayıların oluşturulması, toplanması ve farklarının alınması işlemleri yapılabilmektedir. Maschietto ve Soury-Lavergne (2013a,b) Cabri Elem ekitapları ismini verdiği bir dizi teknolojik araçlar arasında e-BÇ'ye de farklı biçimlerde yer vermiştir. Öyle ki bu araçlarda öğrencilere sayıları farklı biçimlerde kullanabilecekleri görevler verilmiş ve kullanıma bağlı olarak e-BÇ aracı öğrencilere uygun geri bildirimlerde bulunacak şekilde tasarlanmıştır. Ayrıca, BÇ aracının aksine, e-BÇ aracında öğrenciler birtakım sinırlılıklarla karşılaşmaktadır. Örneğin BÇ aracında gösterilen sayı 000 iken birler basamağını temsil eden çark bir birim saat yönünün tersinde çevrildiğinde 999 sayısını göstermektedir. Diğer bir ifade ile BÇ en fazla üç basamaklı sayıları temsil edebilmesine rağmen adeta 1000 'den 1'i çıkarma işlemini yapar gibi hareket etmektedir. Bu durumla, e-BÇ aracında karşılaşılmamaktadır (Maschietto ve Soury-Lavergne, 2017).

e-BÇ aracında dişli çarkların döndürülmesi işlemleri öğrencilere sunulan oklarla yapılmaktadır ve öğrenciler sayıların nasıl değiştiğini gözlemleyebilmektedir. Maschietto ve Soury-Lavergne (2017) e-BÇ’nin bu özelliğini doğrudan manipüle edilebilirlik geri bildirimi olarak nitelendirmiştir. BÇ'de öğrenciler turuncu yardımcı çarkları çevirebilirken, e-BÇ'de böyle bir olanak kullanıcılara verilmemiştir. Ayrıca sayılar arasında esnek işlemler yapmayı, yani bir sayıyı farklı iki sayının toplamı veya farkı olarak düşünmeleri cesaretlendirilmiştir. Örneğin, Şekil 3a'da 17 sayısının e-BÇ'de en az tıklamayla oluşturulması istenmektedir. 17 sayısı, 1 onluk ve 7 birlikten oluştuğu için birlikler çarkına $7 \mathrm{kez}$ ve onluklar çarkına $1 \mathrm{kez}$ tıklanarak toplamda 8 tıklama ile 17 sayısı oluşturulmuştur. Her iki çarkta da saat yönündeki oklara tıklanarak ekleme işlemi yapılmıştır. Ancak, e-BÇ bu tür bir oluşumun en az sayıda tıklama olduğu geri bildirimini vermemiştir. Diğer bir yöntemde ise 17 sayısına, 20'den 3 çıkarılarak ulaşılmıştır (Şekil 3b). Bu

\footnotetext{
${ }^{4}$ Türkçe'ye eser, ürün gibi kelimelerle çevrilebilen artifact (veya artefact), Enstrümantal Oluşum Teorisi ışığında bireyin kullanım şeması/teknikleri ve kendisine sağlanan olanak ve sınırlılıklarla enstrüman (instrument) haline dönüşür. Artifact kelimesinin anlamını doğrudan karşılayan Türkçe bir kelime bulunamadığından, artifact kelimesine karşılık olarak araç kelimesinin kullanımı tercih edilmiştir (bkz. Özdemir Erdoğan, 2016).

5 İletişim adresi: Quercetti\& C. S.p.A

C.so Vigevano 25, 10152 - Torino

e-mail: quercitalia@libero.it
} 
anlamda, onluk çarkında saat yönünde bulunan oka 2 kez tıklanmış ve sonrasında ise birlik çarkında saat yönünün tersinde bulunan oka $3 \mathrm{kez}$ tıklanarak toplamda 5 tıklamayla 17 sayısına ulaşılmıştır. e-BÇ 17 sayısına minimum 5 kez tıklanarak ulaşılabileceğini gülen yüz ikonu (Şekil $3 b)$ ile belirtmektedir. Bu ikon kullanıcıya verilmiş bir değerlendirme geri bildirimidir, kaç kez tıklandığının gösterilmesi ise bir strateji geri bildirimi olarak ele alınabilir (bkz. Maschietto ve Soury-Lavergne, 2017).

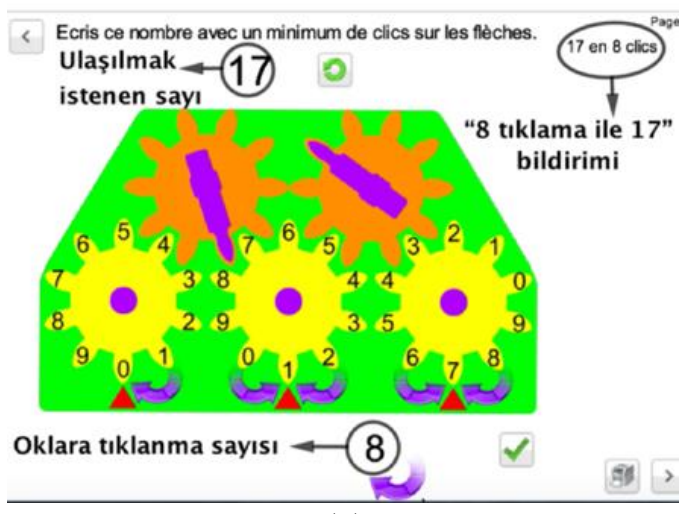

(a)

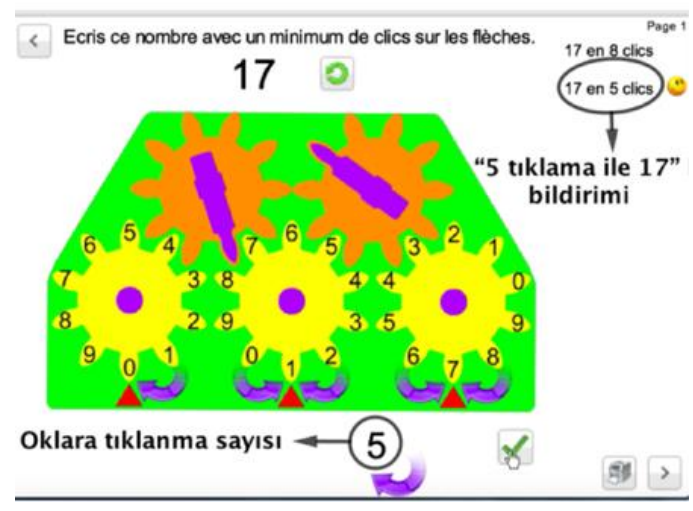

(b)

Şekil 3. (a) 17 sayısına 8 tıklama ile ulaşılması, (b) 17 sayısına 5 tıklamayla ulaşılması

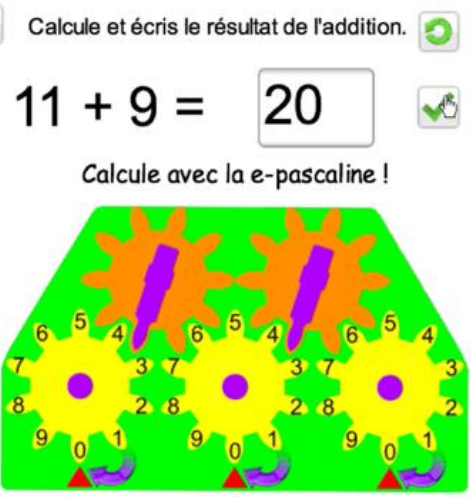

(a)

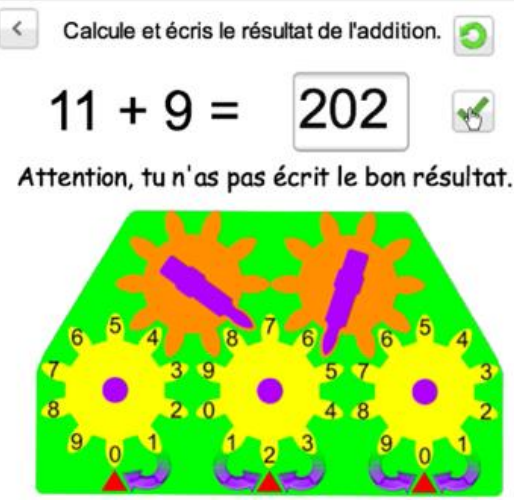

(b)

Şekil 4. (a) Kullanıcıya verilen "hesaplamayı e-pascaline ile yap" uyarısı, (b) Yanlış cevap için verilen değerlendirme bildirimi

e-BÇ iki ve üç basamaklı sayıların toplamını gerektiren bölüme de sahiptir. Bu bölümde ekranda verilen sayıları öğrenciden toplaması ve öğrencinin bulduğu sonucu çarklarla göstermesi istenmektedir. Şayet, e-BÇ kullanılmadan cevap kutucuğa doğrudan yazılırsa, program "hesaplamayı e-pascaline ile yap" uyarısını vermektedir (Şekil 4a). Öğrencinin toplama işlemini nasıl yapacağı konusunda serbesttir. Örneğin istendiği takdirde önce birler basamağındaki sayıları topladıktan sonra onlar basamağındaki sayıların toplamına geçebilir. İkinci bir yöntemde ise önce verilen birinci sayı e-BÇ’ye girilir ve bu sayının üzerine ikinci sayı eklenir. Bunun yanı sıra yanlış cevap verildiğinde ise üzgün yüz ikonu ekranda geribildirim olarak belirmektedir (Şekil 4b).

\section{Basamak değeri çizelgesi (Place value chart)}

Basamak Değeri Çizelgesi (BDÇ) programı, Alman matematik eğitimcisi Prof. Dr. Ulrich Kortenkamp öncülüğünde 2012 yılından itibaren tasarlanmıştır (bkz. Ladel ve Kortenkamp, 2016a,b). BDÇ dokunmaya duyarlı bir iPad ve iPhone uygulaması olup yaklaşık 1 Amerikan doları ücretle App Store üzerinden temin edilebilir. Programda en az iki basamaklı, en fazla dört 
basamaklı sayılar oluşturulabilir. Birler, onlar, yüzler ve binler basamağ 1 birbirlerinden çizgi ile ayrılmaktadır. İlgili bölgeye dokunulduğunda, dokunma sayısı veya ekrana temas eden parmak sayısı kadar daire görünümünde kırmızı pullar (tokens) oluşmaktadır. Bu pullar, Montessori seçeneğiyle beraber istendiği takdirde farklı renkler haline dönüştürülebilir. Benzer şekilde, isteğe bağlı olarak BDÇ'de basamak değerleri, sayının yazılışı ve okunuşu gösterilebilir veya kaldırılabilir. Ayrıca, sayıların tabanlarının değiştirilebileceği programda ondalıklı sayılarla da çalışmaya imkân tanınır (Ladel ve Kortenkamp, 2016a). Ancak, ondalıklı sayıların okunuşları matematiksel olarak okunuşlarından farklı bir biçimde verilmektedir (örneğin 0,254 sayısının okunuşu "sıfır virgül iki beş dört" şeklinde verilmektedir).

BDÇ'de belirli bir basamakta olan pul, başka bir basamağa belirli koşullarda taşınabilmektedir. Örneğin, daha üst basamakta yer alan bir sayı alt basamağa taşınılabilmektedir. $\mathrm{Bu}$ durumda basamaklar arasındaki ilişkiye göre pullar arasında düzenlemeler meydana gelir. Şekil 5a'da verilen 203 sayısındaki bir yüzlük birler basamağına ve bir yüzlük onlar basamağına taşınmasıyla birlikte Şekil 5b'deki gösterim elde edilmiştir. Bu durumda 2 yüzlük +3 birlik gösterimi taşıma işlemi neticesinde 10 onluk +103 birlik şeklinde ifade edilmiş olur. Ancak, birler ve onlar basamağında bulunan sayıların 9 rakamından büyük olması sebebiyle uyarı mahiyetinde 103 birler ve 10 onlar yazısı kırmızı ile gösterilmektedir (Ladel ve Kortenkamp, 2016a,b).

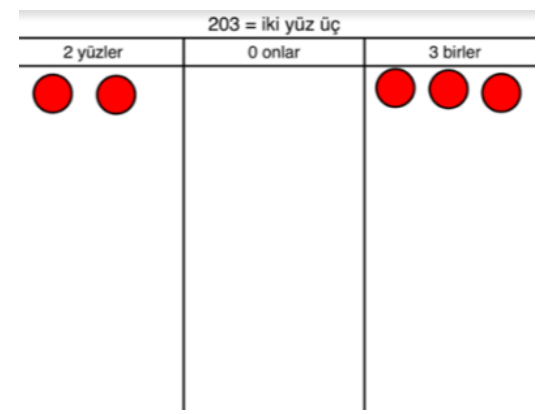

(a)

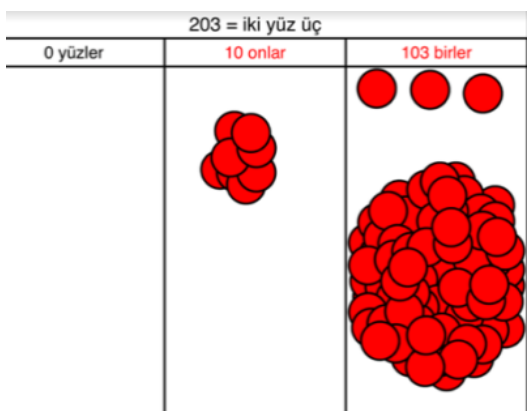

(b)

Şekil 5. (a) BDÇ'de203 sayısı, (b) 1 yüzlüğün birler basamağına ve 1 yüzlüğün onlar basamağına taşınması

Alt basamakta yer alan bir pul, şayet bulunduğu basamakta en az 10 pul yer almıyorsabir üstteki basamağa taşınılabilir. Örneğin, Şekil 6a'da 2 yüzlük ve 12 onluk olarak gösterilen 320 sayısında bulunan onluklardan biri yüzlükler bölümüne taşınırsa (Şekil 6b), bu pulun beraberinde 9 pul daha animasyonla kümelenerek (Şekil 6c) yüzlükler bölümüne taşınır. Bu sayede 2 yüzlük ve 12 onluk yapılan işlemle birlikte 3 yüzlük ve 2 onluğa dönüşür (Şekil $6 \mathrm{~d}$ ). Benzer şekilde bir pulun bulunduğu basamakta en az 100 pul varsa, bu pul doğrudan iki basamak üste taşınılabilir. Alt basamakta yer alan bir pul, şayet bulunduğu basamakta en az 10 pul bulundurmuyorsa bir üst basamağa taşınamaz (bkz. Ladel ve Kortenkamp, 2016a).

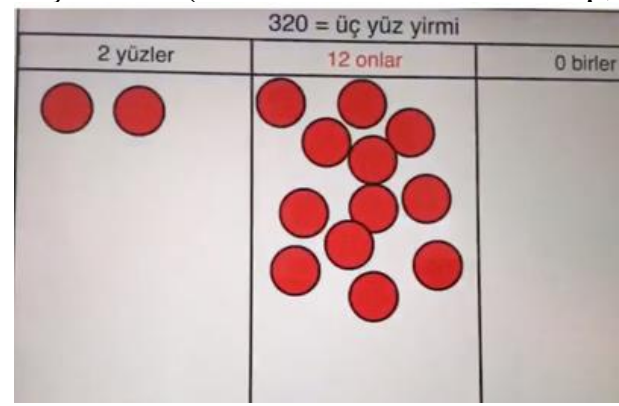

(a)

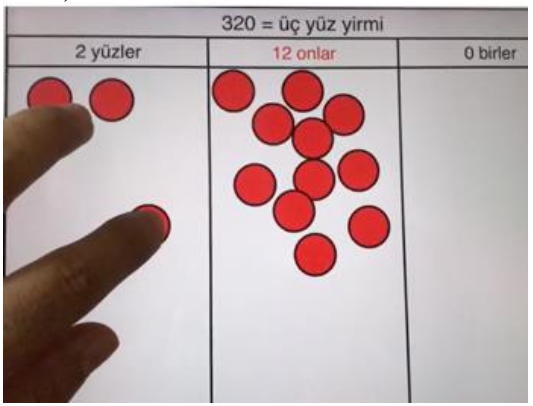

(b) 


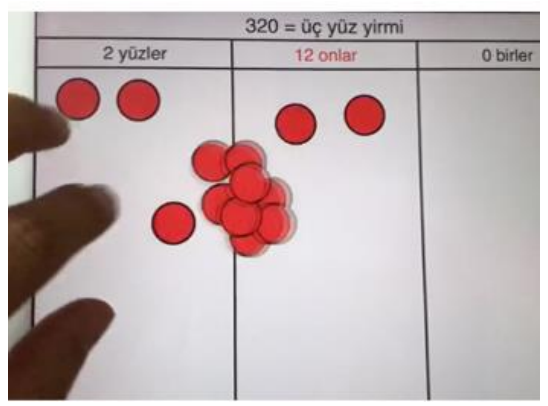

(c)

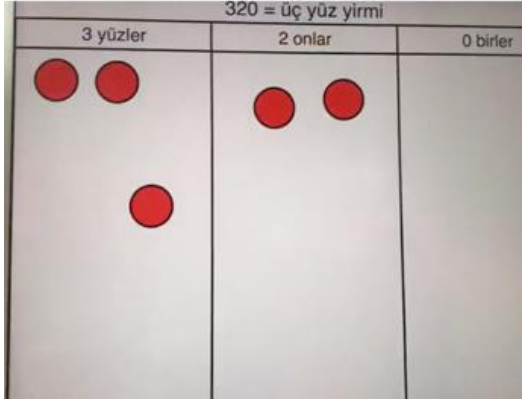

(d)

Şekil 6. (a) 2 yüzlük ve 12 onluk olarak 320, (b) onluk pullarından birinin yüzlükler bölümüne taşınması, (c) onluklar bölümündeki 9 pulun animasyonla diğer pulun üzerine taşınması, (d) 320 'nin 3 yüzlük ve 2 onluk biçimine dönüşmesi

BDÇ her ne kadar sayıların basamak ve sayı değerlerinin gösterilmesi, yazılması ve okunmasına yönelik olmasına rağmen farklı kullanım biçimlerine göre aritmetik işlem yapmaya da olanak sağlar (Ladel ve Kortenkamp, 2016a; Monaghan, 2016). Örneğin Monaghan (2016) BDÇ programının özellikle eldeli toplama işleminin kavramsal anlamaya yardımcı olur nitelikte olduğunu ifade etmiştir. Diğer yandan, çıkarma işlemine özgü kullanım şeması geliştirilerek ekranın bir kısmı çıkan, bir kısmı ise fark olarak ele alınabilir. Şekil 7'de 134 sayısından 48 sayısının çıkarılma aşamaları verilmiştir. Bu süreçte, ekranın üst kısmında çıkan sayı olacak şekilde pullar hareket ettirilmişken, ekranın alt kısmında çıkarma işlemi sonucunda elde edilen farka ulaşılmıştır. İstendiği takdirde, çıkan sayı ekranın alt kısmında, fark ise ekranın üst kısmında da tutulabilir. Görüldüğü üzere, BDÇ'de eldeli çıkarma işlemi yapmak bir dizi adımları dikkatli bir şekilde planlama ve uygulama ile gerçekleştirilebilir. Dolayısıyla, çıkarma işlemi yaparken hatalarla karşılaşılması olağan görülmektedir.
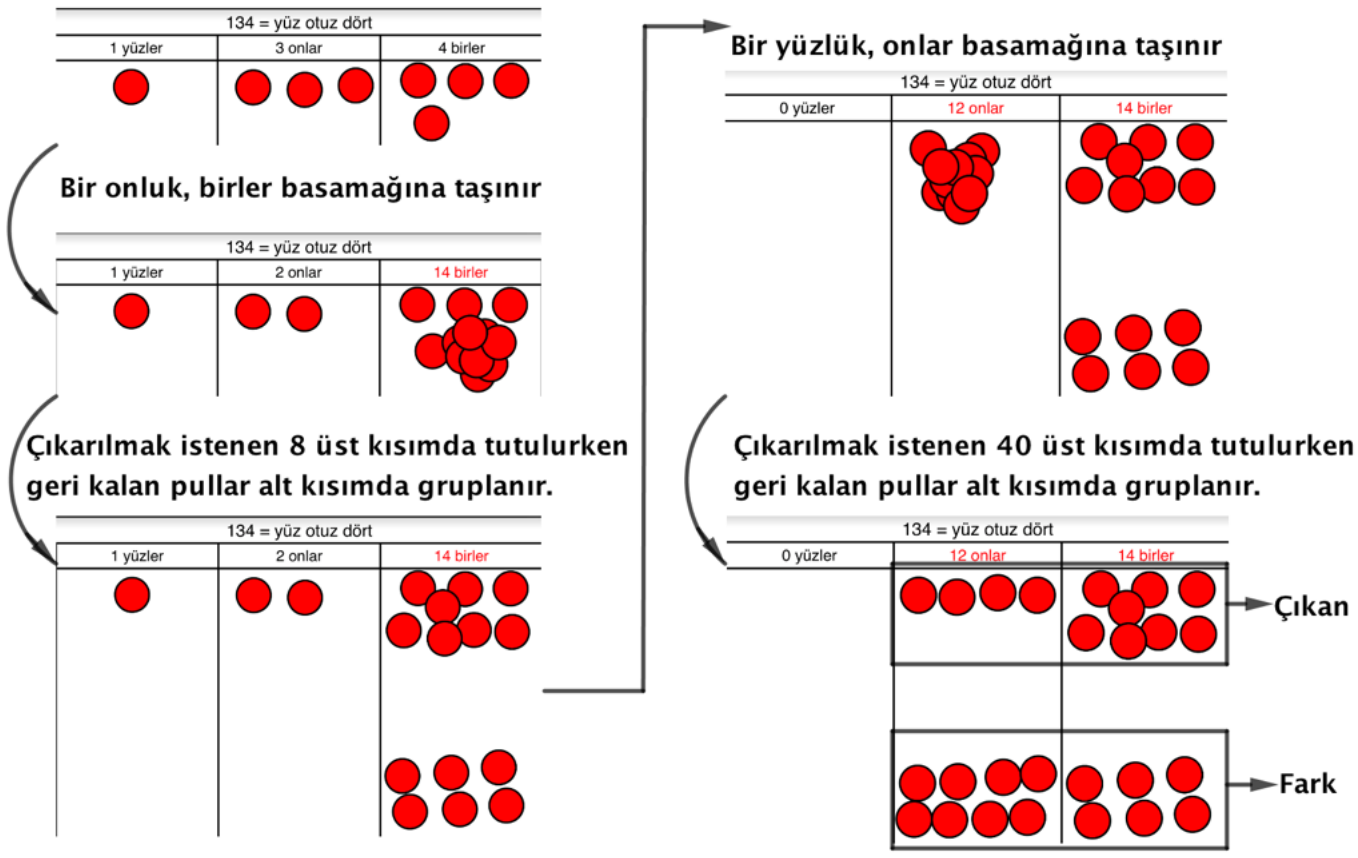

Şekil 7. BDÇ’de 134'ten 48 çıkarma aşamaları

\section{Dokunma sayar (TouchCounts)}

Dokunma Sayar (DS) programı, 2011 yılı başlangıçlı Somut Matematik Projesi (Tangible Mathematics Project) kapsamında Kanadalı araştırmacılar tarafından geliştirilmiştir. Ayrıca aynı araştırma grubu Temmuz 2019'dan itibaren özellikle çarpma işlemi için geliştirilmiş Türkçeye 
Dokunma Çarpar (DÇ) olarak çevrilebilen Touch Times ${ }^{6}$ isimli programı da farklı dillerde kullanıma sunmuşlardır. Yazılımda kullanılabilecek diller ise İngilizce, Almanca, İtalyanca ve Fransızca'dır. DS ve DÇ programları bir iPad uygulaması olarak kullanılmakta ve ücretsiz olarak indirilebilmektedir. Somut Matematik Proje sayfasında DS kullanımı 3-8 yaş grubuna, DÇ ise 611 yaş grubuna önerilmektedir. DÇ programı çoğunlukla çarpma işlemine yönelik olması sebebiyle bu çalışmada incelenmesi kapsam dışına bırakılmıştır.

DS dokunma temelli bir program olup ekranda dokunma sayısını algılayabilmektedir. Ses özelliği kullanıma açıldığında, program seçilen dilde sayıları dokunmaya bağlı olarak okumaktadır. Programda iki farklı bölüm bulunmaktadır: sayılar dünyası (the Numbers World) ve işlemler dünyası (the Operations World). Sayılar dünyasında bir adet çizgi bulunmaktadır. Bu çizginin (veya rafın) üst bölgesine dokunulduğunda ilgili sayı ekranda tutulurken, çizginin alt kısmına dokunulduğunda ilgili sayı ekrandan yok olmaktadır. Bu bölümde sayılar dokunma sayısına göre sirasıyla gelmektedir (Sinclair, 2018; Sinclair ve Zaskis, 2017). Bu anlamda öğrencilere tek sayıların, çift sayıların, üç ve üçün katları gibi sayıları rafın (shelf) üzerinde tutma görevleri verilebilir. Örneğin, öğrencilerden tek sayıları rafin üstüne dizmeleri istendiğini düşünelim. Şekil 8a'da gösterildiği gibi 1, 3ve 5 sayısı çizginin üst kısmında herhangi bir yere tıklandığ 1 için rafın üzerine konumlanmıştır. Buna karşın, 2., 4. ve 6. kez ekrana dokunmayla oluşan sayılar çizginin alt kısmında tıklandığı (örn. Şekil 8b) için sayılar aşağıya doğru düşerek (örn. Şekil 8c) ekrandan kaybolmuştur.

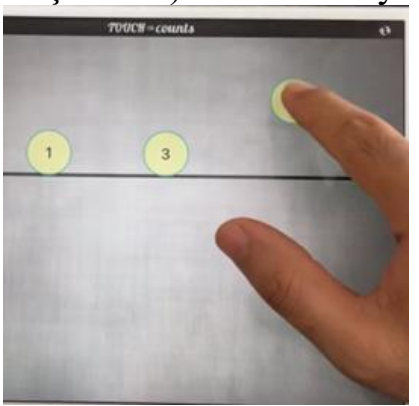

(a)

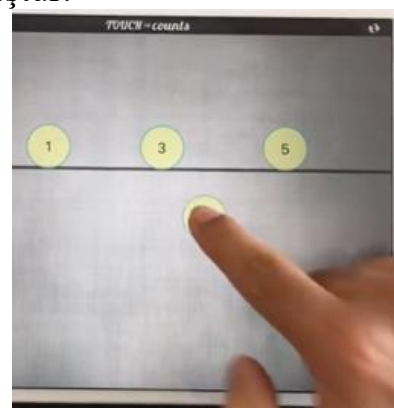

(b)

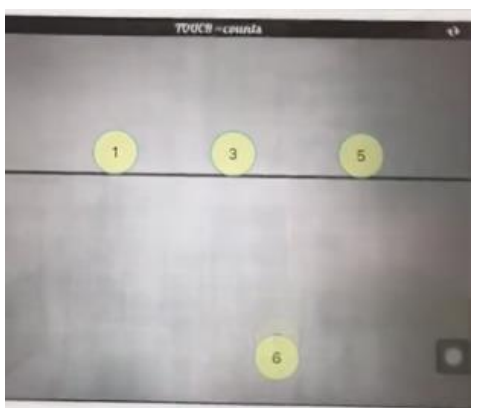

(c)

Şekil 8. (a) 5. kez ekrana tıklanmasıyla 5 sayısının oluşması, (b) Çizginin alt kısmına denk gelecek şekilde ekrana 6. kez tıklanması, (c) 6 sayısının aşağıya doğru düşmesi

DS'nin bir diğer bölümü olan işlemler dünyasında ise temel olarak toplama ve çıkarma işlemi yapılabilmektedir. Ekrana temas eden parmak sayısına göre küme gösterimini çağrıştıran bir sayı topluluğu (numberherd) oluşur. İlk etapta temas eden parmakların konumuna göre DS birebir eşleme yaparak dağınık bir sayı topluluğu oluşmasına rağmen (Şekil 9a) kısa sürede sayı topluluğu içindeki sayıları temsil eden diskler düzenli bir gösterim oluşacak şekilde konumlanır. $\mathrm{Bu}$ sayı topluluklarına yeni sayılar eklenebilir veya sayı topluluklarından sayı çıkarma işlemi yapılabilir. Farklı iki veya daha fazla sayı topluluğunu toplayabilmek için, toplanılması istenen sayı toplulukları seçilip üst üste getirilir (Şekil 9b). Bu işlem sonucunda daha büyük bir sayı topluluğu elde edilmiş olur (Şekil 9c) (Sinclair, 2018; Sinclair ve Zaskis, 2017).

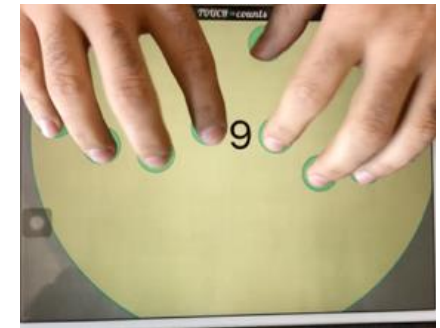

(a)

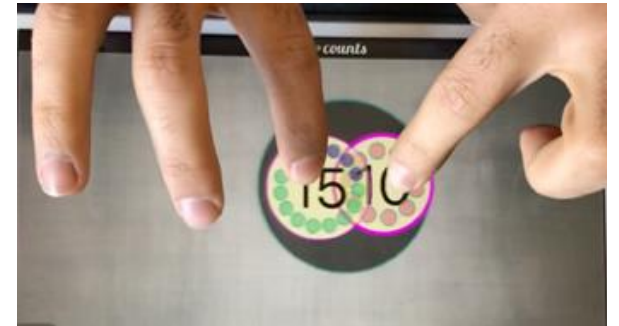

(b)

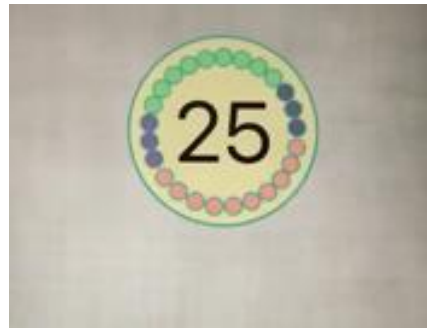

(c)

${ }^{6}$ TouchTimes erişim adresi: https://apps.apple.com/ca/app/touchtimes/id1469862750?mt=8 
Şekil 9. (a) DS'de 9 sayısının oluşturulması, (b) 15 ile 10 sayılarının toplanması, (c) Toplama işlemi sonucunda sayı topluluğunda oluşan 25 sayısı

Bir sayı topluluğundan başka bir sayı topluluğu çıkarılmak istendiğinde, büyük olan say1 topluluğu bir parmak ile tutulurken, başka bir parmakla çıkarılması istenilen sayı kadar disk, sayı topluluğundan dişa doğru çekilir. İstenilen sayıya ulaşıldığında sayı topluluğu serbest bırakılır ve çıkarma işlemi yapılmış olur (Sinclair, 2018; Sinclair ve Zaskis, 2017). Örneğin, Şekil 10a'da 25 sayısından 5 çıkarmak amacıyla 25 sayı topluluğunun iç bölgesinde herhangi bir yer bir parmakla tutulmuş ve başka bir parmakla 5 disk dışarı doğru çekilmiştir. Sayı topluluğundan çıkarılacak diskler içi boş bir görünüm alır. Dışa doğru çekilen parmağa göre eksilen disk sayısı ayarlanabilmektedir. Yani, parmak daha uzağa doğru çekildikçe, sayı topluluğundan çıkan disk sayısında da artış meydana gelir. Bu işlem sonunda 25 sayısı, 20 ve 5 sayı toplulukları halinde parçalanır (Şekil 10b). Her ne kadar DS'deki işlemler dünyası bölümü toplama ve çıkarma işlemleri için tasarlanmış olsa da farklı işlemler yapmaya da olanak verir. Örneğin, Şekil 10c'de 25 sayısı katlamalı çıkarma mantığı ile 5 eş sayıda disk içeren sayı topluluklarına ayrıştıııldığında 5'e bölme işlemi gerçekleştirilmiş olur.

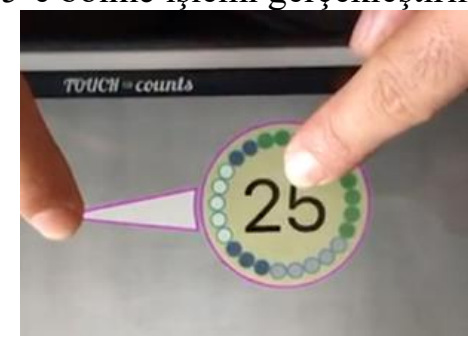

(a)

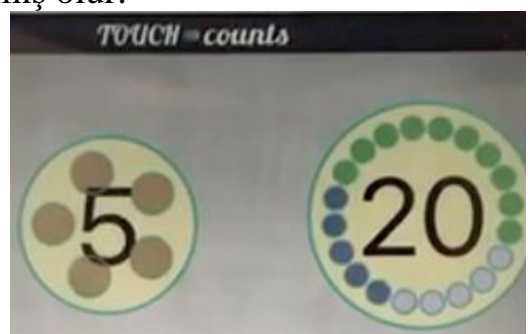

(b)

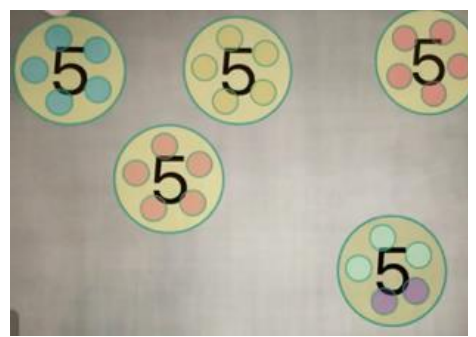

(c)

Şekil 10. (a) 25 sayısından 5 çıkarma işlemi, (b) 25 sayısının 20 ve 5 olarak parçalanması, (c) 25 sayısının 5'e bölümünün gösterimi

Teknolojik araçların sayıların ordinallik ve kardinallik anlamına göre incelenmesi

$\mathrm{Bu}$ bölümde e-BÇ, BDÇ ve DS araçları sayının ordinallik ve kardinallik anlamına göre sınıflandırılmıştır. Ayrıca, bu araçlarda sıfırın anlamına değinilerek basamak değeri bakımından araçlar incelenmiştir.

\section{e-BC aracında sayının anlamı}

Cabri Elem e-kitapları arasında yer alan ve BÇ somut materyalinin eşleniği olan e-BÇ'de öğrenciler en fazla üç basamaklı sayıları oluşturulabilmektedir. Ancak, öğrencilere bazı kısıtlamalar konulmuştur. Örneğin, yüzler basamağının 0 (sıfır) olduğu durumda çıkarma işlemi yapmaya yarayan ok öğrencilere verilmemektedir (Şekil 11a). Diğer bir kısıtlama ise yardımcı çarkların (turuncu çarklar) çevrilememesidir (bkz. Şekil 11a-b) (Maschietto ve Soury-Lavergne, 2013b, 2017). Öyle ki yardımcı çarkların çevrilmesi, teknolojik araçta birincil öneme sahip değildir. Yardımcı çarklar daha ziyade, birlik, onluk ve yüzlük çarklarının çevrilmesiyle beraber doğru sayı ve basamak değerlerinin elde edilmesinde aracılık rolü üstlenir. Ayrıca, yüzler basamağının 0 olduğu durumda, çıkarma işleminin yapılmasına izin verilmemesi ordinallik anlamında öğrencilerin kafa karışıklığı yaşamamaları için alınan önlemdir. Bu bölümde, bir sayının programda en az tıklamayla nasıl oluşturabileceği ile ilgili bir yönlendirme yapılmamaktadır. $\mathrm{Bu}$ durumda sayıların parçalanarak e-BÇ'de oluşturulmasına yönelik bir yönlendirme yapılmadığından, öğrenciler sayıları istediği biçimde oluşturabilirler. Örneğin, 37 sayısına çok sayıda yöntemle ulaşılabilir. Göstergenin sıfır (000) olarak ayarlandığ 1 e-BÇ’ de, birliklerdeki dişler $37 \mathrm{kez}$ saat yönünde çevrilmesiyle beraber 37 sayısına ulaşılır. Bu süreçte yardımcı çarklar eldeli işlemleri gerçekleştirir. Ancak, 37 sayısına ulaşabilmek için dişliyi $37 \mathrm{kez}$ çevirmek sabır ve süreklilik gerektirir. 


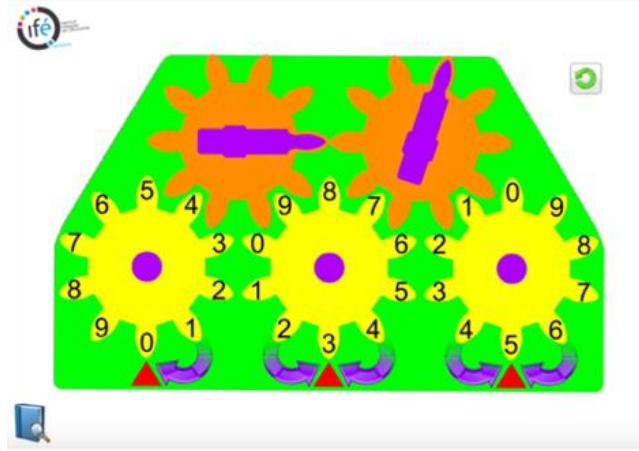

(a)

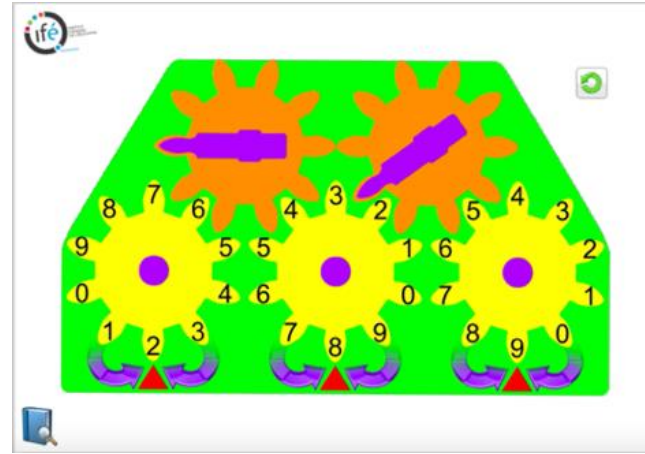

(b)

Şekil 11. (a) Yüzler basamağındaki göstergedeki sayının 0 olması sebebiyle saat yönünün tersini göstermesi gereken okun aktif olmaması, (b) yüzler basamağının göstergesindeki sayı 0'dan farklı olduğu için okun aktif duruma gelmesi

Benzer şekilde 350 sayısına ulaşmak için birliklerde bulunan dişliyi 350 kez çevirmek daha fazla emek gerektiren bir kullanım biçimidir. Dolayısıyla ulaşılmak istenen sayıyı göstergede daha az zaman harcayarak gösterme isteği oluşur. Bu da basamak değerine geçmeye veya basamak değeri fikrini kullanmaya zemin hazırlar. Örneğin, 10 kez birlikler çarkındaki dişler çevrildiğinde onlar basamağındaki göstergenin 0'dan 1'e geçmesiyle birlikte birlikler çarkının 10 birim çevrilmesinin onluklar çarkının 1 birim çevrilmesine denk olduğu anlașilır. Bu da 1 onluğun 10 birlik olduğu fikrini verir. Öğrencilerin en çok tercih edeceği yöntemlerden biri de birlikler çarkındaki dişlileri saat yönünde 7 kere çevirdikten sonra, onluklar çarkındaki dişliyi yine saat yönünde 3 kere çevirip 37 sayısına ulaşılması olur. Ya da tam tersi, öğrenci önce onluklar çarkındaki dişlileri 3 kez çevirip sonrasında birlikler çarkındaki dişlileri 7 kez saat yönünde hareket ettirebilir. Birinci durumda, 37 sayısı 37 birlik olarak ele alınırken, ikinci durumda ise 3 onluk, 7 birlik (veya 7 birlik 3 onluk) olarak elde edilmiş olur. İstendiği takdirde, 37 sayısı için 2 onluk 17 birlik gibi farklı birleşimler yapılabilir. Görüldüğü üzere yazılım sayılar arasında esnek dönüşümler yapmaya olanak sağlamaktadır. Yani, öğrenciler çarkları kullanarak bizzat yazılımla etkileşime girebilmekte ve amaçlı eylemlerde bulunabilmektedir. Ayrıca, çark çevirme eylemine bağlı olarak, göstergelerde bulunan rakamlar anlık olarak güncellenmekte ve buna bağl1 olarak uygun görseller yazılımda gösterilmektedir. Maschietto ve Soury-Lavergne (2017) çocukların sayıları birlikler, onluklar, yüzlükler şekilde parçalara ayırarak (decomposing) e-BÇ’de gösterdiklerini gözlemlemiş ve bu da e-BÇ'de basamak değeri fikrinin kullanıldığını göstermiştir. Maschietto ve Soury-Lavergne (2013b) verilen bir saylya ulaşabilmek için dişlinin kaç kez hareket ettirilmesinin saptanmasına yönelik olarak matematiksel formül sunmuştur. 3 basamaklı bir sayı üzerinden örnek verilecek olunursa:

$$
\text { say } \iota=y \times 10^{2}+o \times 10+b
$$

formülünde oklara toplam tıklanma sayısı $y+o+b$ 'dir. Burada, $y$ harfi yüzler basamağındaki sayı değeri, $o$ harfi onlar basamağındaki sayı değeri ve $b$ harfi birler basamağındaki sayı değeridir (bkz. Maschietto ve Soury-Lavergne, 2013b, s. 968). Diğer yandan, e-BÇ'de basamak değerinin kullanımı sayının en az tıklamayla oluşturulmasında da karşımıza çıkmaktadır. Yani, bir sayıyı bir başka iki sayının farkı olarak e-BÇ'de gösterilebilmesi, sayılar arasında esnek dönüşümler yapıldığına işaret eder. Aynı örnek üzerinden gidilecek olunursa, 37 sayısına ulaşabilmek için öncelikle onluklar çark1 4 kez saat yönünde çevrilip göstergede 40 sayısına ulaşılır ve sonrasında birliklerdeki çarklar $3 \mathrm{kez}$ saat yönünün tersinde çevrilerek yapılan işlem sonucunda 40'tan 3 çıkarılmış olur. Bu durumda, e-BÇ'de bulunan oklara daha az sayıda tıklanmış (7 tıklama) olmakla birlikte 4 onluktan 3 birlik çıkarılarak sayılar arasında esnek dönüşümler yapılmış olur. e-BÇ'de sıfırın konum anlamı vardır, öyle ki göstergedeki her bir çark sıfıra getirilecek șekilde düzenlenmeli ve bir işleme başlanırken bu konuma göre ilerlemeler yapılmalıdır. Burada özellikle ilerleme kelimesi kullanılmıştır çünkü gösterge sıfırı gösterdiğinde, çıkarmayı temsil eden saat yönünün tersindeki okların kullanımı aktif değildir (Şekil 12a). Yalnızca, sıfır sayısının 
üzerine ekleme yapılabilir. Örneğin, yazılımda 0'dan 1 çıkarılmasına izin verilseydi, çıkarma işlemi sonucunda elde edilen sayı 999 olacaktı. Yazılımda yapılan kısıtlamayla birlikte 0-1=999 şeklindeki yanlış matematiksel bilginin önüne geçilmiştir. Benzer şekilde 999 sayısına herhangi bir sayı eklenmemesinin önüne geçilerek yazılımda yanlış matematiksel bilgi oluşumu engellenmiştir. Diğer yandan, bu araçta sayının ordinallik anlamı hâkimdir. Öyle ki, sayılar sıralama ilişkisine bağlı olarak göstergede oluşturulmakta, 0 ve 999 hariç her sayıdan bir önce ve bir sonra gelen sayılar dişli çark çevirme işlemleri ile gözlenebilmektedir. Benzer bir durum sayıların 10'arlı veya 100'erli artırılmasıyla da gözlenebilmektedir (örn. 150 sayısı 50 ile 250 arasındadır veya 150 sayısı 140 ile 160 arasındadır). Yani, sayılar arasındaki durum, dişleri çevirme işlemiyle birlikte gözlemlenebilmektedir.

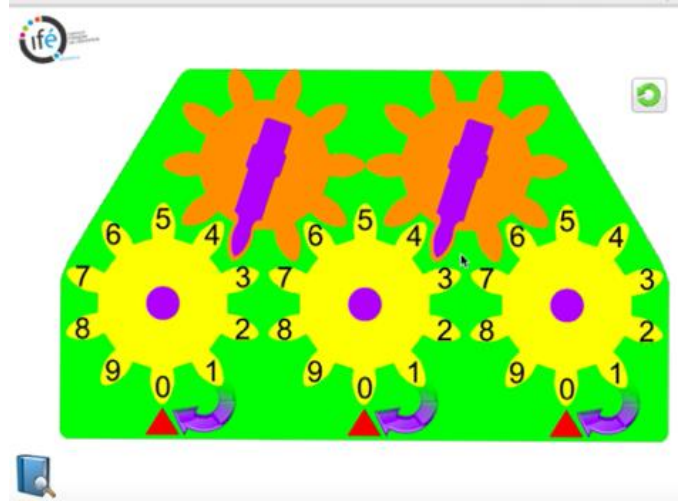

(a)

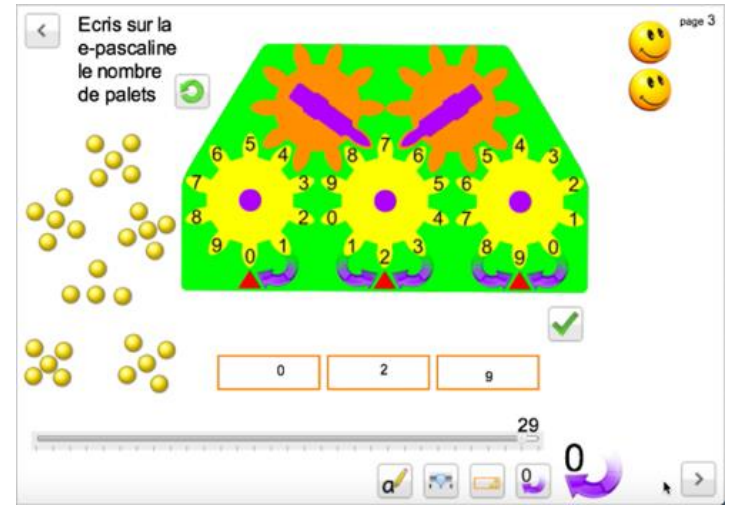

(b)

Şekil 12. (a) e-BÇ'de sıfırın gösterilmesi, (b) e-BÇ'de doğrudan ordinallik ve kardinallik özelliklerinin birlikte kullanılması

e-BÇ aracının sayıları ordinal bir düzende sunması, sayının kardinal anlamına açık olmadığı anlamına gelmemektedir. Çocukların sayıları oluştururken birer birer çarklı dişleri çevirmelerini nicelik olarak değerlendiren Maschietto ve Soury-Lavergne (2017), çocukların sayıları parçalayarak basamak değerlerine geçişlerini gözlemlemiştir. Bu durumda, e-BÇ’ de sıralı olarak gelen sayıların kardinallik tarafı da kullanılmış olur. Ayrıca, e-BÇ’nin başka bir sayfasında hem ordinallik hem de kardinallik özellikleri doğrudan öne çıkarılmıştır. Örneğin, Şekil 12b'de çoğunluğu beşerli olarak gruplanmış disklerin (toplamda 29 disk), e-BÇ'de gösterilmesi istenmektedir. İsteğe bağlı olarak metin kutusu seçilip her bir basamak ayrı ayrı belirtilebilir, oklara tıklanma sayısı gösterilebilir ve uzunluğu çağrıştıran doğru üzerinde sayının değeri 29 olarak ayarlanabilir (Şekil 12b). Böylece, işleyişi sayının ordinalliğini temel alan hem BÇ hem de e-BÇ araçlarında sayının kardinallik anlamı ordinallikle birlikte ön plana çıkarılmış olur.

\section{BDÇ'de sayının anlamı}

BDÇ aracında, binlikler, yüzlükler, onluklar, birlikler basamağındaki sayı değerleri verilmiş, yani standart parçalamaya dayalı oluşturulan bir sayının basamakları arasında esnek geçişler sağlanmaktadır. Bu bağlamda, standart formda olan bir sayıya BDÇ'de standart olmayan güçlü parçalama veya standart olmayan parçalama uygulanabilmektedir (Ladel ve Kortenkamp, 2016b). Standart olmayan güçlü parçalanmaya (strongn on standard partitioning) 231 sayısı üzerinden örnek verilecek olursa, bu sayının BDÇ'de oluşturulmasında en az bir basamağı boş bırakılır (23 onluk +1 birlik, 2 yüzlük +31 birlik veya 231 birlik). Standart olmayan parçalamada (non standard partitioning) ise, her basamakta en az bir say1 yer alır ( 1 yüzlük +13 onluk +1 birlik, 2 yüzlük +1 onluk +21 birlik vs.) (bkz. Ladel ve Kortenkamp, 2016b, s. 293). Dolayısıyla, basamak değeri bağlamında öğrenciler kasıtlı ve amaçlı şekilde yazılımı kullanabilme olanağına sahiptir. Dokunmaya hassas olan bu iPad yazılımında hata yapmak (örneğin kazayla bir basamağa fazladan bir sayı girmek) küçük yaştaki çocukları için olasıdır. Ancak, yazılımda geri al menü aracı bulunmaması sebebiyle, yapılan herhangi bir yanlış doğrudan düzeltilememektedir. Hata 
yapıldığında yapılabilecek tek şey uygulamadan çıkıp tekrar geri dönmektir. Ancak bu durumda, uygulamada yapılan her şey kaybolmaktadır.

BDÇ'de sıfır sayısının gösterilmesi için ekrana herhangi bir şekilde dokunulmaması gerekmektedir. $\mathrm{Bu}$ durumda $\mathrm{BDÇ}$ 'de “0 = sıfır" gösterilir ve ekranda herhangi bir pul görünmediğinden, sıfır hiçlik veya yokluk anlamına gelir. Basamaklar arasındaki esnek geçişler ise öncelikli olarak kardinal anlamda yapılır. Ladel ve Kortenkamp $(2016 a, b)$ kardinal anlama yönelik olarak yığınlama (bundle) ve yığını çözümleme (unbundle) ifadelerini kullanmışlardır. Örneğin, üst basamakta yer alan bir pul halihazırda yığınlanmış durumda olduğu için bir alt basamağa taşındığında, sayı demeti çözümlenmiş olur ve bu eylemin sonucunda bir alt basamakta 10 tane kümelenmiş pul belirir. Şayet üst basamakta yer alan pul demeti iki alt basamağa taşınırsa, bu durumda iki alt basamakta 100 tane kümelenmiş pul oluşur (bkz. Şekil 5). Yığını çözümleme durumunda özellikle sayının kardinal anlamı daha belirgin hale gelir.

Yığın oluşturma sürecinde bir basamakta bulunan 10 adet pul demet haline getirilerek, bir üst basamağa taşınmaktadır (bkz. Şekil 13a-b). Bu eylem için, ilgili basamaktaki herhangi bir pul bir üst basamağa taşındığında beraberinde 9 pul daha animasyonla kümelenerek taşıma işlemi sonuçlandırılır. Şayet, o basamakta en az 10 adet pul bulunmuyorsa, sayının bir üst basamakta yığınlanmasından söz edilemez. İlgili basamakta en az 10 pulun bulunmadığı bir durumda, yazılım öğrenciye yine de pulu bir üst basamağa taşımaya izin vermektedir. Fakat öğrenci elini puldan çektiğinde bu pul alınan basamağa otomatik olarak geri gitmektedir. Bu durumda öğrenci herhangi bir eylemde bulunduğunda (pulu bir üst basamağa taşıma gibi) yazılım bu eyleme uygun bir geri bildirim vermektedir. Ancak, yığın oluşturmada, yani pul demeti oluşturmada kardinallik anlamın zayıfladığını söylemek mümkündür. Örneğin, Şekil 13a'daki 10 onluk, yığın oluşturma kabulüyle bir yüzlük haline Şekil 13b'de gösterildiği gibi dönüştürülmüştür. Şekil 13a ve Şekil 13b karşılaştırıldığında, basamaklar arası taşıma işlemiyle beraber pulların nicelik olarak azalması ile sonuçlandığı kanısı oluşabilir. BDÇ'deki 234 sayısında yüzlükleri ve onlukları sayı demeti şeklinde düşünecek olursak, sezgisel olarak Şekil 13c'deki üç boyutlu gösterime gidilebilir ${ }^{7}$. Yani, bir üst basamağa taşıma işlemi yapıldığında, nicelik bakımından azalmış gibi görünen pulların aslında üst üste istiflendiği düşünülebilir. Bu durumda BDÇ’nin, pul yığınlarını üstten görünüm perspektifiyle verdiği (iki boyutta), yani sadece en üstteki pulu gösterdiği varsayılır. Böylece nicelik bakımından herhangi bir kayba uğranmadığı düşünülebilir. O halde, Şekil 13c'deki gösterim, sayıları nicelik olarak ele aldığı için basamak değerinin birlik, onluk ve yüzlük bloklar ile gösterilmesi ile benzerlik gösterir (bkz. Şekil 14a).

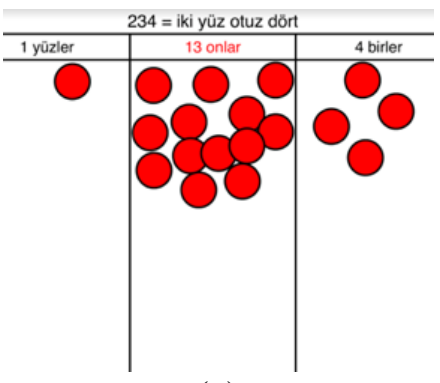

(a)

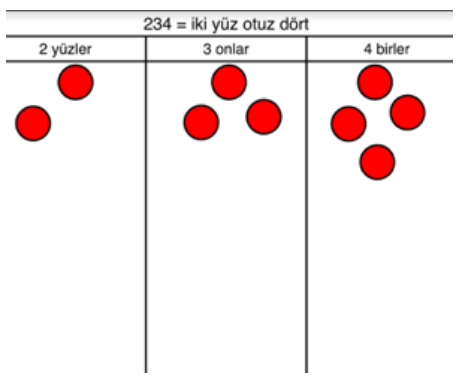

(b)

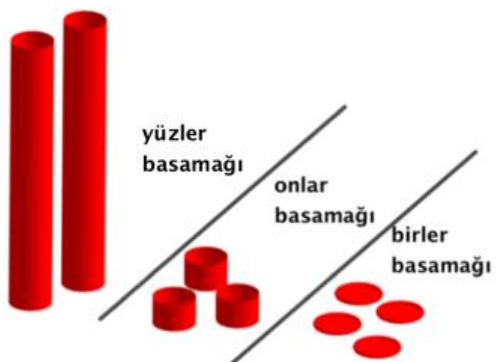

(c)

Şekil 13. (a) 1 yüzler, 13 onlar, 4 birler olarak parçalanmış 234 sayısı, (b) onlar basamağındaki bir pulun yüzler basamağına taşınmasıyla oluşan standart biçimdeki 234 sayısı, (c) Üç boyutta pulların yığınlanması fikri ile gösterilmiş 234 sayısı

Ladel ve Kortenkamp (2016b) Almanyalı ve Lüksemburglu 3. sınıf öğrencileri üzerinde yaptıkları araştırmada bazı öğrencilerin nicelik olarak 10'u, basamak değerindeki 10 ile karıştırdıklarını gözlemlemiştir. Örneğin 314 sayısındaki onlar basamağına bazı öğrencilerin 1 yerine 10 tane pul çizdikleri sonucuna ulaşmıştır (bkz. Şekil 14b). Araştırmacılar bu sonuçtan

\footnotetext{
${ }^{7}$ Bu yorumlama yazara aittir. Ladel ve Kortenkamp'ın (2016a,b) BDÇ'de pulları üst üste ekleyerek silindiri çağrıştıran yığınların oluşturulduğuna yönelik herhangi bir açıklaması yoktur.
} 
hareketle, onluk taban bloklarının basamak değeri öğretiminde kullanılmaması gerektiğini vurgulamış ve taban blokları yerine BDÇ'de olduğu gibi her basamaktaki sayı değerinin sayılabilen işaretlerle gösterilmesi gerektiğini ifade etmiştir. $\mathrm{Bu}$ durumda, Ladel ve Kortenkamp'ın iddiasına göre “10'u (veya 100'ü) temsil eden blok ile bir onluğu (veya bir yüzlüğü) temsil eden sayma pulu birbirine karışmaz" (s. 306).

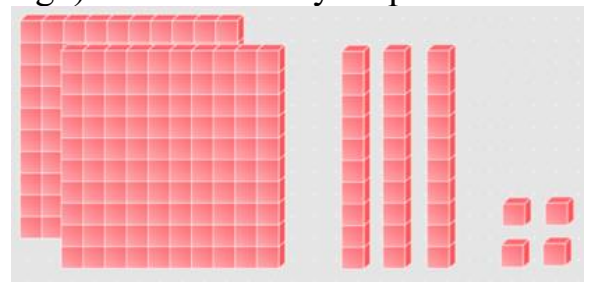

(a)

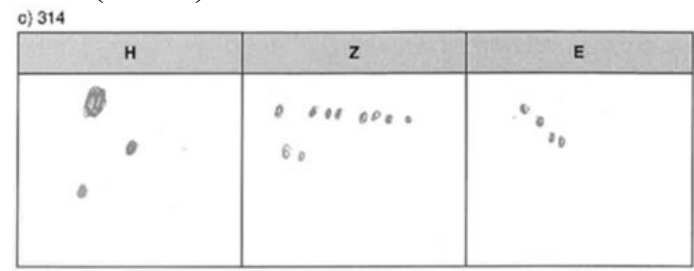

(b)

Şekil 14. (a) Taban bloklarıyla 234 sayısının gösterimi, (b) bir öğrencinin 314 sayında nicelik olarak 10’u basamak değerinde kullanması (Ladel ve Kortenkamp, 2016b, s. 303)

BDÇ'de ondalık sayıların okunuşundaeksiklikler göze çarpmaktadır. Örneğin, Şekil 15'te gösterilen 2,204 sayısının okunuşu "iki virgül iki sıfır dört" şeklinde belirtilmiştir. Yazılımda verilen bu okuma şekli Türk dili açısından eksiklik içermektedir. Okul matematiğinde bu sayının "iki tam binde iki yüz dört" șeklinde ifade edilmesi beklenmektedir. Ya da özellikle günlük hayat dilinde bu sayı "iki virgül iki yüz dört” şeklinde de okunabilmektedir. Dolayısıyla, BDÇ'de ondalık sayıların okunuşu bakımından uygun bir geri bildirim sağlanmamaktadır.

2,204 = iki virgül iki sıfır dört

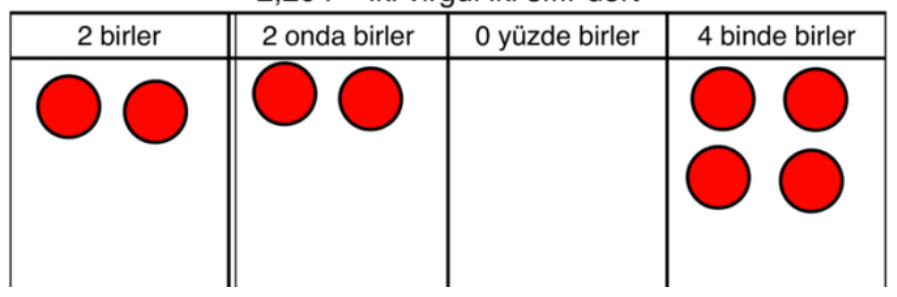

Şekil 15. BDÇ'de 2,204 ondalık sayısının gösterimi

Her ne kadar kardinallik BDÇ’de ağırlık göstermekte olmasına rağmen, Ladel ve Kortenkamp $(2012,2014)$ yaptıkları bir çalışmada çocukların pulları ordinal anlamda da saydığını gözlemlemiştir. Çalışmada çocuklardan 6 sayısını pullarla göstermeleri istenmiştir. Örneğin bir çocuk, parmaklarını teker teker ekrana değdirmiş ve parmakları arasında bir sıra takip etmiştir. Çocuk, ordinallikle özdeşleştirilebilen birinci parmak, ikinci parmak gibi ifadeler kurarak pulları ekranda oluşturmuş ve sonunda oluşturduğu pulların 6 tane olduğunu belirtmiştir (Ladel ve Kortenkamp, 2012). Bu durumda, sıralı olarak sayılarla eşleştirilen parmakların saymada ordinal anlamda kullanıldığı görülmektedir.

\section{DS'de sayınin anlamı}

Daha önce de ifade edildiği gibi DS, Sayılar Dünyası ve İşlemler Dünyası bölümü olmak üzere iki ayrı bölümden oluşmaktadır. Sayılar Dünyası bölümünde ekrana temas edilmesiyle birlikte üzerinde sayılar yazılmış ve birbirine eş görünümde olan diskler sıralı halde ekranda belirir. Bu sebeple Sayılar Dünyası bölümünde sayının ordinallik anlamı ön plandadır. Şayet raf olarak da isimlendirilebilen ekrandaki çizginin üzerinde bir kısma dokunulmuşsa sayılar rafın üzerinde tutulurken, çizginin alt bölgesine tıklanmasıyla oluşan sayılar aşağıya doğru hareket ederek ekrandan kaybolurlar. Sayılar birer birer oluşturulabilirken, isteğe bağlı olarak birden fazla sayıda parmak ekrana temas ettirilip sayılar oluşturulabilir. Örneğin, Şekil 16a' da gösterildiği gibi, tek sayıların raf üzerinde tutulması istendiğinde, her parmak sırayla ekranın uygun bölümlerine temas ettirilir ve sayılarla birebir eşlenir. Yani, tek sayılar için rafın üst kısmına, çift sayılar için rafın alt kısmına temas edilir. Parmaklar ekrandan çekildiğinde, çizginin üst kısmındaki sayılar rafın 
üzerine düşerken, çizginin alt kısmındaki sayılar ekrandan aşağıya doğru yönelerek kaybolur (bkz. Şekil 16b-c). Her ne kadar sayının ordinallik anlamı Sayılar Dünyası Bölümünde baskın olsa da rafın üst kısmında sayılar sırasıyla dizilerek niceliğe de vurgu yapılabilir. Sinclair ve Zazkis (2017) sayılar dünyasının hem kardinal hem de ordinal unsurlar içerdiğini belirterek, bu bölümde disklerin üzerinde sayıların belirtilmesindeki amacı: "genç kullanıcıları [çocukları] saymaya geçişlerini harekete geçirmektir" (s. 180) şeklindeifade etmişlerdir.

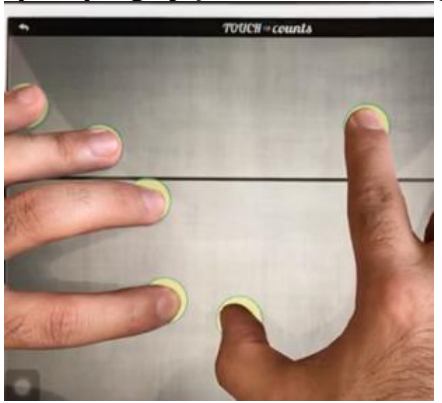

(a)

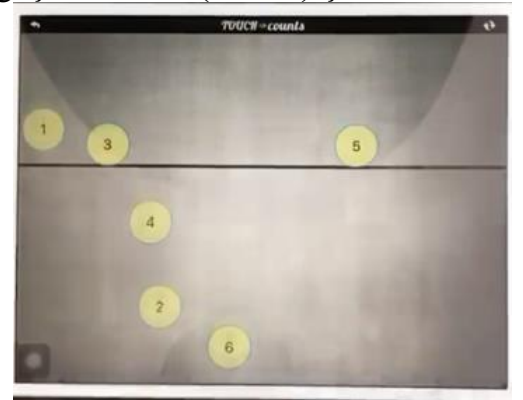

(b)

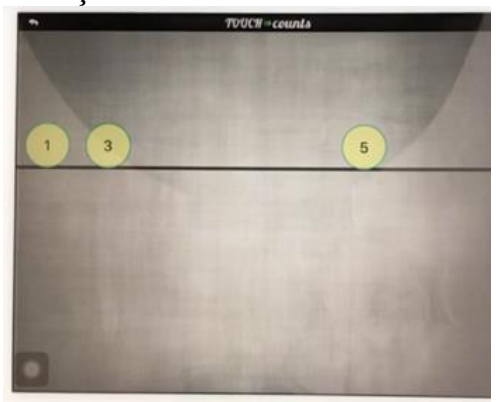

(c)

Şekil 16. (a) Çizginim alt ve üst ekranlarına parmaklarla tıklanması, (b) çizginin üst ve alt tarafındaki sayıların aşağıya doğru hareket etmesi, (c) çizginin alt tarafındaki sayıların ekrandan kaybolmas1

DS'nin İşlemler Dünyası bölümünde ise her bir parmak birebir sayılarla eşlenip bir sayı topluluğu (herd) oluşturduğundan, bu bölümde sayının kardinal anlamı daha ön plandadır. Öyle ki sayı toplulukları nicelik olarak ele alınmakta, sayıların değeri arttıkça sayı topluluklarının kümelendiği diskleri içeren dairelerin çapı da artmaktadır. Ancak, sayılarla birebir eşlenen sayı topluluklarının içerisinde yer alan diskler, sayının değeri arttıkça daha da küçülmektedir (bkz. Şekil 17a). Bu da iki ve üç basamaklı sayıların ekranda oluşturulmasına imkân sağlamaktadır. Ancak, belirli bir sayıdan sonra 3 basamaklı sayılar, ekrana sığmamakta ve ekran dışına taşmaktadır. DS Sayılar ve İşlemler Dünyasında öğrencilerin kasıtlı ve amaçlı bir şekilde eylemlerde bulunabilmelerine olanak sağlanmaktadır. Ayrıca yazılımda gerçekleştirilen bir eyleme yönelik uygun sonuç (geri bildirim, görsel vs.)yazılımda öğrenciye verilmektedir.

DS İşlemler Dünyasında basamak değeri kavramının oluşturulması e-BÇ’ye ve BDÇ’ye göre farklılık göstermektedir. Yani, e-BÇ'de ve BDÇ'de basamaklar arasında kurallar yazılımı geliştiren araştırmacılar tarafından tasarlanmışken(örneğin e-BÇ'de sıfırı gösteren bir dişlinin aynı yönde $10 \mathrm{kez}$ çevrilmesi bir sonraki basamağın sayı değerini 1 artırır/azaltır, BDÇ'de 10 pul bir say1 yığını oluşturur), DS'de basamak değeri adına oluşturulmuş bir kural yoktur. Örneğin Şekil 17a'da verilen 146 sayısı, Şekil 17b'de 6 birlik, 4 onluk ve 1 yüzlük olacak şekilde parçalanmıştır. Ancak, yazılımda yalnızca 1 rakamı ekranda bağımsızca hareket etmekte ve kimi zaman kısa süreli ekrandan kaybolmaktadır. Bu durum öğrenciler açısından teknoloji ara yüzüyle ilgili kafa karışıklığına neden olabilme potansiyeline sahiptir. Basamak değerine vurgu yapılmaksızın yazılımda herhangi bir sayı istendiği takdirde, 9'luklara, 15'liklere vs. parçalanabilir. DS'de büyük sayıların parçalanması güçlü bir psikomotor beceri gerekmektedir. Örneğin, küçük yaştaki çocuklar için bir seferde 146'dan 10 çıkarmak zahmetli bir eylem olabilir. Aksine, toplama işlemi yapılması (sayı topluluklarının birleştirilmesi) çok daha kolay yapılabilmektedir. Ayrıca, 3 basamaklı sayıları oluşturmak e-BÇ’ye ve BDÇ’ye göre daha uzun zaman alır. 


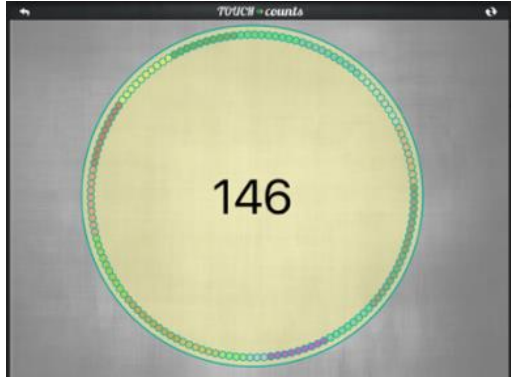

(a)

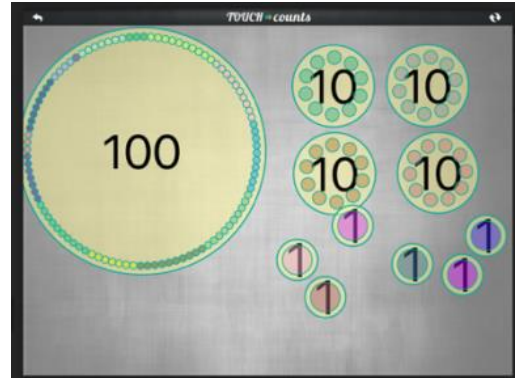

(b)

Şekil 17. (a)DS'de 146 sayısı, (b) 146 sayısın yüzler, onlar ve birler olarak parçalanması

Coles ve Sinclair (2017) 2. sınıf öğrencilerinin kardinallik anlamının baskın olduğu DS İşlemler Dünyasında sayıları birbirine eklerken aynı zamanda sayılara ordinallik açısından yaklaştıklarını gözlemlemiştir. Öğrenciye 70 ve 10 sayı kümeleri gösterilmiş ve bu iki sayıyı birbirine eklediğinde kaça ulaşacağ 1 sorulmuştur. Öğrenci, 80 sayısını öğrenmemesine rağmen, 10'arlı sayıların sonuna "-ty" ekinin geldiğini dikkate alarak "eighty" cevabını vermiştir. Cevaba nasıl ulaştığ1 sorulan öğrenci, "8'in 7'den sonra geldiğini biliyorum”" (s. 3) şeklinde bir açıklama yaparak toplama işlemine ordinal anlamda yaklaşmış ve işlemi basamak değeri çerçevesinde yürütmüştür. Başka bir öğrenci ise 90 ile 10 sayısını toplarken "ten-ty" cevabını vermiştir. Ordinal anlamda 9'dan sonra 10'un gelmesini ilişkilendirebilen öğrenci burada dilsel bir engele takılmıştır çünkü İngiliz dilinde 100 için yeni bir kelime olan "one hundred" kullanılmaktadır. Örneklerden de anlaşılabileceği üzere kardinallik özelliği baskın olan DS İşlemler Dünyasında, öğrenciler sayılara ordinal anlamda da yaklaşabilmektedir.

DS'de 0 (sıfır) diğer programlara göre daha örtük bir şekilde karşımıza çıkmaktadır. Öyle ki sıfırın gözlemlendiği tek yer İşlemler Dünyasında bir sayıdan kendisinin çıkarılması sırasında gözlemlenmektedir (Şekil 18a-b). O halde sıfır, hiçlik veya yokluk anlamına gelir. Keza, çıkarma işlemi sonucunda herhangi bir sayı topluluğu oluşmamakta ve 0 sayısı kısa süre içerisinde ekrandan kaybolmaktadır.

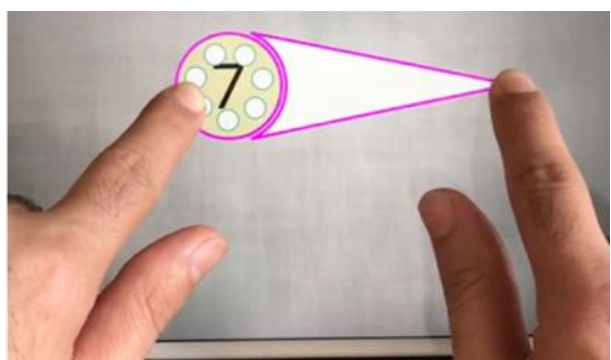

(a)

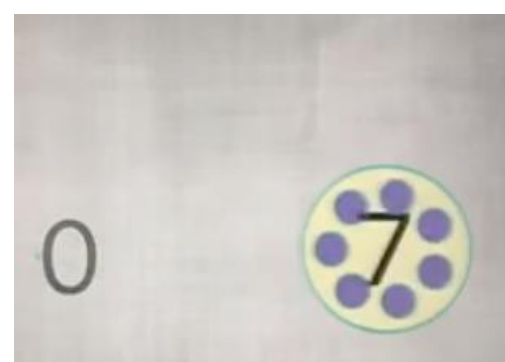

(b)

Şekil 18. DS İşlemler Dünyasından 7'den 7 çıkarılması, (b) Çıkarma işlemi sonucunda 0 rakamının soluk bir şekilde gösterilmesi

\section{Sonuçlar ve Öneriler}

Bu çalışmada e-BÇ, BDÇ ve DS araçları sayının ordinallik ve kardinallik anlamları bakımından incelenmiş, sıfırın anlamı ve basamak değeri üzerinden yazılımlar değerlendirilmiştir. e-BÇ'de sayının ordinallik yönünün ağır bastığı, BDÇ’de ise kardinallik yönünün ön planda olduğu sonucuna ulaşılmıştır. DS'de ise sayının her iki anlamının mevcut olabileceği görülmüştür. Yani, Sayılar Dünyası bölümünde ordinalliğin, İşlemler Dünyası bölümünde ise kardinalliğin vurgulandığı görülmüştür. Ancak, her üç araçta da eksik olan sayı anlamının da (kardinallik veya ordinallik) ortaya çıkarılabileceği düşünülmektedir. Bu anlamda, öğrencilerden istenebilecek görev türlerinde hem ordinalliğin hem de kardinalliğin kullanılabileceği durumlar ele alınabilir. Örneğin, e-BÇ'de sayının kardinal anlamının ele alınması için nicelikler kullanılabileceği, ordinal anlamı için ise birbirine bağımlı çarkların kullanım mekanizmaları üzerinden sayıların 
oluşturulabileceği durumlar ortaya konulabilir. Diğer yandan, ordinal anlama sahip olan DS Sayılar Dünyasında ise, sayılar raf üzerinde biriktirilip nicelik bakımından da sayılara vurgulamalar yapilabilir.

Sıfırın anlamının BDÇ ve DS araçlarının hiçlik veya yokluk olarak ele alındığı düşünülürken e-BÇ aracında sıfır konum anlamındadır. Şayet, e-BÇ'de konum anlamında olan sıfır, başlangıç pozisyonunda bulunan çarkların hiç çevirmemesi olarak düşünüldüğünde sıfır hiçlik anlamına da gelebilir. Basamak değeri bakımından, e-BÇ ve BDÇ araçlarında, bu araçların tasarımcıları tarafından basamaklar arasında kurallar konulmuştur. Örneğin, e-BÇ'de gösterge sıfirdayken bir diş saat yönünde 10 birim çevrildiğinde, çark bir tam tur atar ve bir sonraki çarkı 1 birim hareket ettirir. Bu durumda alt basamaktaki 10 birim ilerleme, üst basamaktaki 1 birim ilerlemeye denk gelir. BDÇ'de ise sayı demetlerinin 10'lu olarak gruplanması ve çözümlenmesi söz konusudur. Alt basamaktan üst basamağa geçişte en az 10 pul yoksa, bir üst basamakta say1 demeti oluşturmaktan söz edilemez. Ancak, basamak değeri bakımından, aynı sayı birden fazla şekilde ifade edilebileceğinden, basamak değerinin esnek bir şekilde ele alınabileceği görülmüştür. Anlaşılacağı üzere bu iki aracı (e-BÇ, BDÇ) kullanan öğrenciler, araç tasarımcılarının geliştirdikleri kullanım mekanizmaları dışına çıkamamaktadır. Diğer yandan, DS aracında ise (İşlemler Dünyası bölümünde) sayılar istenildiği şekilde parçalanabilmekte veya gruplanabilmektedir (5'likler, 20'likler vs.). Ancak, sayıların onluklar, birlikler gibi basamaklarla ifade edilmesi bu durumda eğitimcilere (öğretmen vs.) düşmektedir. Aksi halde, sayıların standart basamak değerlerinin ifade edilmesinde öğrencilerin zorluk yaşayabileceği öngörülmektedir.

e-BÇ, BDÇ ve DS araçlarının matematik eğitimcileri tarafından geliştirilmesi ve bu araçların kullanımına dair araştırma sonuçlarının özellikle matematik eğitimi alanyazınında rastlanması sebebiyle, bu çalışmada ismi geçen üç araç değerlendirilmiştir. Ancak, sayıların ordinallik ve kardinallik anlamı üzerine kullanılabilecek teknolojik araçlar çalışmalarda değerlendirilen araçlarla sınırlı değildir. Bu anlamda araştırmacılar, sayının anlamına dair başka teknolojik araçlar üzerine çalışma tasarlayabilirler. Ayrıca, bu çalışma sayının kardinallik ve ordinallik anlamlarıyla sınırlıdır. Sayının farklı anlamları üzerine de araştırmalar tasarlanabilir (bkz. Akkaya 2019; Baki, 2018; Fuson, 1988).

Her ne kadar sıralı sayma, sayının kardinalliğinden önce geldiği düşünülse de (bkz. Toluk ve Uçar, 2003), Colomé ve Noël (2012) okul öncesi dönemdeki çocukların sayıların kardinallik anlamını, ordinallik anlamına göre daha kolay edinebildiklerini gözlemlemiştir. Ancak, bu tür bir çıarım çocukların teknolojik araçların kullanılmasına dayalı olarak yapılmamıştır. Bu bağlamda, özellikle okulöncesinde veya ilkokul eğitiminin ilk yıllarında öğrenim gören çocuklar üzerinde, e-BÇ, BDÇ, DS gibi araçların kullanılması sağlanarak araç kullanımı sürecinde ordinallikkardinallik arasındaki etkileşimlerinin ne şekilde kurulduğu, araç kullanımına bağlı olarak bu iki anlamın nasıl oluşturulduğu araştırılabilir. Ayrıca, sayının anlamlarının bu tür araçlarla etkileşim sonucunda, çocukların yaşı ve zihinsel gelişimine göre nasıl farklılık gösterdiğine yönelik enlemsel veya boylamsal araştırmalar tasarlanabilir. Sayıların öğrenimine yönelik geliştirilmiş araçların kullanım ve işleyiş mekanizmalarının birbirlerinden farklılık göstermesi nedeniyle, araştırmanın amacına yönelik ölçütler çerçevesinde en uygun aracın veya araçların seçilmesi önemli görülmektedir.

$\mathrm{Bu}$ derleme çalışmasında incelenen e-BÇ, BDÇ, DS yazılımları, Almanya, Kanada gibi ülkelerde araştırma amaçlı kullanılmaktadır. Dolayısıyla, bu yazılımların ülkemizde kullanılmasının önünde birtakım engellerin olabileceği düşünülmektedir. Öncelikle bu ve buna benzer yazılımlardan bir kısmı yalnızca iPad destekli olduğundan, öğrencilerin aktif tutulduğu sınıf içi uygulamaların yapılması olası görünmemektedir. Ayrıca bu tür yazılım kullanılması küçük gruplar halinde veya öğretmen denetiminde bireysel çalışmayı gerektirdiğinden ilgili teknolojik araçların temin edilebilmesi maliyet bakımından yüksektir. Bunun yerine etkileşimli tahtalarda kullanılabilen ücretsiz veya maliyeti düşük yazılımlar tercih edilebilir. Bu bağlamda ögretmen tarafından ilgili yazılımın ordinallik ve kardinallik anlamında incelenmesi, belirlenen sorunlara veya yazılımdaki eksikliklere yönelik önlemlerin alınması daha etkili bir öğrenme açısından önem teşkil etmektedir. 
e-BÇ, BDÇ, DS gibi farklı işleyiş ve kullanım mekanizmalarına sahip araçların öğretmen eğitimine yönelik uygulamalarından da söz edilebilir. Öyle ki, öğretmen adaylarına ve hizmet içinde özellikle sınıf öğretmenlerine yönelik eğitimler verilebilir. Sayının farklı anlamları çerçevesindebu tür araçlar tasnif edilip, sayının farklı anlamlarını birlikte kullanmaya yönelik etkinlik yazma eğitimi verilebilir. Ancak, öğretmenlerin veya öğretmen adayların araçlar üzerindeki düşünceleri, tutumları, inançları gibi araştırmalardan ziyade, e-BÇ, BDÇ, DS gibi etkileşimli araçların sınıf içinde kullanımlarının yansımaları (örn. araç, öğrenci, öğretmen, arasındaki etkileşimler) veya öğretmenlerin/öğretmen adaylarının sayının farklı anlamlarını bu araçlarla nasıl ortaya çıkardıkları üzerine araştırma ihtiyacı olduğu düşünülmektedir.

\section{Etik kurul izin bilgilendirmesi}

$\mathrm{Bu}$ derleme çalışması, retrospketif bir yapıya veya insan/hayvan deneklerinin kullanımına dayalı olmadığından etik kurul izni gerektirmemektedir.

\section{Kaynaklar}

Akkaya, R. (2019). Sayılar, sayma ve sayı kavramı. B. Durmaz (Yay. haz.). Erken Çocuklukta Matematik Ĕgitimi içinde (ss. 145-164). Ankara: Pegem Akademi.

Alptekin, S. (2015). Sayma becerilerinin öğretimi. Ankara Üniversitesi Eğitim Bilimleri Fakültesi Özel Eğitim Dergisi, 16(1), 63-74.

Argün, Z., Arıkan, A., Bulut, S. ve Halıcıoğlu, S. (2014). Temel matematik kavramlarının künyesi. Ankara: Gazi Kitabevi.

Arslan, S. ve Ubuz, B. (2015). Sayılarda basamak değeri kavramı ve öğrencilerin yaşadığı zorluklar. E. Bingölbali ve M. F. Özmantar (Yay. Haz.). İlköğretimde Karşılaşıllan Matematiksel Zorluklar ve Çözüm Önerileri içinde (5. bask1) (s. 97-126). Ankara: Pegem Akademi.

Baki, A. (2018). Matematiği öğretme bilgisi. Ankara: Pegem Akademi.

Bartolini Bussi, M. G., Inprasitha, M., Arzarello, F., Bass, H., Kortenkamp, U., Ladel, S., ... Soury-Lavergne, S. (2018). Aspects that affect whole number learning: Cultural artefacts and mathematical tasks. M. G. Bartolini Bussive ve X. H. Sun (Yay. haz.). Building the Foundation: Whole Numbers in the Primary Grades içinde (ss. 181-226). Cham: Springer.

Bishop, J. P., Lamb, L. L., Philipp, R. A., Whitacre, I. ve Schappelle, B. P. (2014). Using order to reason about negative numbers: The case of Violet. Educational Studies in Mathematics, 86(1), 39-59.

Bruce, R. A. ve Threlfall, J. (2004). One, two, three and counting. Educational Studies in Mathematics, 55(1-3), 3-26.

Coles, A. ve Sinclair, N. (2017). Re-thinking place value: From metaphor to metonym. For the learning of mathematics, 37(1), 3-8.

Colomé, À. ve Noël, M. P. (2012). One first? Acquisition of the cardinal and ordinal uses of numbers in preschoolers. Journal of Experimental Child Psychology, 113(2), 233-247.

Demircioğlu, H. (2016). Sayı kümeleri. A. N. Elçi, E. Bukova Güzel, B. Cantürk Günhan ve E. Ev Çimen (Yay. haz.). Temel Matematiksel Kavramlar ve Uygulamaları içinde (ss. 1118). Ankara: Pegem Akademi.

Fuson, K. C. (1988). Children's counting and concepts of number. New York: Springer-Verlag.

Gelman, R.ve Gallistel, C. R. (1978). The child's understanding of number. London: Harvard University Press.

Ladel, L. ve Kortenkamp, U. (2011) Finger-symbol-sets and multi-touch for a better understanding of numbers and operations. M. Pytlak, T. Rowland ve E. Swoboda (Yay. haz.). The Seventh Congress of the European Society for Research in Mathematics Education (CERME 7) içinde (ss. 1792-1800). Rzeszów: The University of Rzeszów.

Ladel, S.ve Kortenkamp, U. (2012). Early maths with multi-touch-an activity-theoretic approach. Erişima dresi: https://cermat.org/poem2012/main/proceedings_files/Ladel-KortenkampPOEM2012.pdf 
Ladel, S. ve Kortenkamp, U. (2014). Number concepts-processes of internalization and externalization by the use of multi-touch technology. U. Kortenkamp, B. Brandt. C. Benz, G. Krummheuer, S. Ladel ve R. Vogel (Yay. haz.). Early Mathematics Learning: Selected Papers of the POEM 2012 Conference içinde (ss. 237-253). Dordrecht: Springer.

Ladel, S. ve Kortenkamp, U. (2016a). Artifact-centric activity theory - A framework for the analysis of the design and use of virtual manipulatives. P. Moyer-Packenham (Yay. haz.). International Perspectives on Teaching and Learning Mathematics with Virtual Manipulatives içinde (ss. 25-40). Cham: Springer.

Ladel, S.ve Kortenkamp, U. (2016b). Development of a flexible understanding of place value. T. Meaney, O. Helenius, M. L. Johansson, T. Langeve, A.Wernberg (Yay. haz.). Mathematics Education in theEarly Years: Results from the POEM2 Conference, 2014 içinde (ss. 289-307). New York: Springer.

Lakoff, G. ve Núñez, R.E. (1997). The metaphorical structure of mathematics. L.D. English (Yay. haz.). Mathematical Reasoning: Analogies, Metaphors, and Images içinde (ss. 21-89). Mahwah, NJ: Lawrence Erlbaum Associates.

Maschietto, M. ve Soury-Lavergne, S. (2013a). The beginning of the adventure with pascaline and e-pascaline. E. Faggianove A. Montone (Yay. haz.). The 11th International Conference on Technology in Mathematics Teaching içinde (ss. 194-199). Bari: UniversitàdegliStudi di Bari.

Maschietto, M.ve Soury-Lavergne, S. (2013b). Designing a duo of material and digital artifacts: The pascaline and Cabri Elem e-books in primary school mathematics. ZDM-The International Journal on Mathematics Education, 45(7), 959-971.

Maschietto, M. ve Soury-Lavergne, S. (2017). The duo "Pascaline and e-Pascaline": An example of using material and digital artefacts at primary school. E. Faggiano, F. Ferrara ve A. Montone (Yay. haz.). Innovation and Technology Enhancing Mathematics Education içinde (ss. 137-160). Cham: Springer.

Monaghan, J. (2016). The calculator debate. J. Monaghan, L. Trouche ve J. M. Borwein (Yay. haz.). Tools and Mathematics: Instruments for Learning içinde (ss. 305-331). Cham: Springer International Publishing.

Mutlu, Y., Olkun, S. ve Cumhur, F. (2019). Dokunsay sayı tabletlerinin okul öncesi çocuklarının aritmetik becerileri üzerindeki etkisinin incelenmesi. Illkögretim Online, 18(1), 437-450.

Olkun, S., Çelik, E. ve Sönmez, M. T. (2017). İlköğretim birinci sınıf Türk öğrencilerinde sayma ilkelerinin gelişimi. Başkent University Journal of Education, 1(2), 115-125.

Olkun, S., Fidan, E. ve Babacan-Özer, A. (2013). 5-7 yaş çocuklarda sayı kavramının gelişimi ve saymanın problem çözmede kullanımı. Ĕgitim ve Bilim, 38(169), 236-248.

Olkun, S. ve Toluk, Z. (2003). Illköğretimde etkinlik temelli matematik öğretimi. Ankara: Maya Akademi.

Özdemir Erdoğan, E. (2016). Enstrümantal oluşum teorisi. E. Bingölbali, S. Arslan ve İ. Ö. Zembat (Yay. haz.). Matematik Eğitiminde Teoriler içinde (ss. 803-818). Ankara: Pegem Akademi.

Pimm, D. (2018). On number language: A commentary on Chapter 3. M. Bartolini Bussi ve X. Sun (Yay. haz.). Building the Foundation: Whole Numbers in the Primary Grades: The 23rd ICMI Study içinde (s. 71-87). New York: Springer.

Sedaghatjou, M.ve Campbell, S. R. (2017). Exploring cardinality in the era of touch screen-based technology. International Journal of Mathematical Education in Science and Technology, 48(8), 1225-1239.

Sinclair, N. (2018). Time, immersion and articulation: Digital technology for early childhood mathematics. I. Elia, J. Mulligan, A. Anderson, A. Baccaglini-Frank ve C. Benz (Yay. haz.). Contemporary research and perspectives on early childhood mathematics education içinde (ss. 205-221). Cham: Springer.

Sinclair, N.ve Zazkis, R. (2017). Everybody counts: Designing tasks for Touch Counts. A. Leung ve A. Baccaglini-Frank (Yay. haz.). Digital technologies in designing mathematics 
education tasks. Mathematics education in the digital era (MEDE) book series içinde (Vol. 8, ss. 175-192). Cham: Springer.

Ross, S. R. (2002). Place value: Problem solving and written assessment: Research, reflection, practice. Teaching Children Mathematics, 8(7), 419-424.

Tall, D. (2013). How humans learn to think mathematically: Exploring the three worlds of Mathematics. New York: Cambridge University Press.

Yıldırım, A. ve Şimşek, H. Sosyal bilimlerde nitel araştırma yöntemleri (11. baskı). Ankara: Seçkin Yayıncılık.

Extended Abstract

\section{Introduction}

As Tall (2013) emphasized, "in counting we collect individual objects into collections and count those collections" (p. 97). This view of graspable objects as numbers (e.g., tokens, daily life objects) emphasizes the cardinal aspect of number, which gives students ideas about what magnitude-based numbers look like. It is not uncommon for students to substitute numbers with their fingers when they perform an arithmetical operation. In the same vein, they use hands-on manipulatives (e.g., abacus) or digital artifacts to develop a sense of numbers (Bartolini Bussi et al., 2018). In addition to the cardinal aspect of number, in recent years, the ordinal aspect of number has received a great deal of attention in the mathematics education field. As Coles and Sinclair (2017) underline, "ordinality refers to the aspect of number that is linked to the sequence of counting numbers" (p.4). The researchers stress that the ordinality aspect of number, particularly in digital artifacts, remains an understudied phenomenon. The purpose of this paper is to characterize three digital artifacts (e-Pascaline, Place Value Chart, and Touch Counts) pertaining to the ordinal and/or cardinal aspects of number. Also, the selected digital artifacts are examined pertaining to the place value of numbers and how 0 (zero) is represented.

\section{Selected Digital Artifacts}

Pascaline is a hands-on artifact that enables students to perform arithmetic up to three-digit numbers. It contains teeth that are attached to five wheels. The three lower gears change the digits of numbers (ones, tens and hundreds) via the two upper auxiliary gears. Each lower wheel contains ordered numbers from 0 to 9 and can be rotated clockwise or counterclockwise to perform additions or subtractions. Based on the feedback from students' schemes of utilization of Pascaline in mathematics classrooms, Maschietto and Soury-Lavergne (2013a-b) have designed a new artifact, e-Pascaline that is the Pascaline's digital counterpart with built-in affordances and constraints.

In Place Value Chart (PVC), tokens are created when the screen is tapped. It has separator lines between the places and enables students to study up to four-digit numbers. When one token is moved from a higher place to the neighboring lower place, it always unbundles 10 tokens in the lower place. On the other hand, only if a place contains at least 10 tokens, moving one token to the neighboring higher place bundles 10 tokens in the higher place (Ladel and Kortenkamp, 2016a-b).

Touch Counts (TC) contains two sections: The Numbers World (aka the Enumerating World) and the Operations World (aka the Operating World). In the Numbers World, numbers that are sequentially ordered are created when the screen is tapped. A shelf (a horizontal line) divides the screen horizontally in two. If the tapped number is above the shelf, then the enumerated number lands on the shelf. On the other hand, if it is below the shelf, then the enumerated number disappears from the screen. In the Numbers World, numbered sets - that are also known as herds are created by the number of fingers tapped on the screen. Pinching two herds together make the herds merge, while unpinching one herd decomposes it into two smaller herds (Sinclair, 2018; Sinclair and Zaskis, 2017).

\section{Results}


The ordinality aspect of number is emphasized in e-Pascaline, while the cardinality of the number is more prominent in PVC. However, in these artifacts, both aspects of number may be used together implementing tasks that enable students to reason about quantity and the sequence of numbers. For example, in e-Pascaline, countable disks that represent cardinality can be given to students and students may be asked to represent the quantity in e-Pascaline. Here, students also use the ordinality aspect when they rotate the gears clockwise or counterclockwise to accomplish the given task. One may argue that the cardinality aspect of number is lost in Place Value Chart when 10 tokens are bundled in the neighboring higher place considering 10 tokens of uniform size are replaced with 1 token of the same size on the two-dimensional screen.

The Numbers World of TC emphasizes the ordinality of number, while the Operations World highlights cardinality. Similarly, both aspects of numbers are observed when children access number in both sections of TC (see Coles and Sinclair, 2017). For example, in the Numbers World, children may keep some numbers taking into account a mathematical rule (e.g., the multiples of 3) with a focus on ordinality. Then, they may focus on the quantity of the numbers on the shelf that highlights cardinality.

0 (zero) is considered as a starting point or location in e-Pascaline, while it is associated with not having tapped on the screen to create quantities (herds, discs or tokens) in PVC and TC. e-Pascaline, PVC and TC allow for a more flexible understanding of place value for users/children. However, with built-in constraints, children are limited to compose and decompose numbers using the allowed schemes of utilization in those artifacts. Comparatively, the Operation World of TC allows for standard (composing and decomposing number into ones, tens, etc.) and non-standard partitioning (nines, fifteens, etc.).

\section{Concluding Remarks}

This paper highlights the ordinality and cardinality aspects of number in three digital artifacts. There are various digital artifacts that are designed for teaching and learning of numbers (see Bartolini Bussi et al., 2018). New cross-sectional or longitudinal research may indicate how children's approach to number develops over time as they interact with digital artifacts. Another avenue for future research includes introducing artifacts to elementary teachers in professional development programs to highlight different aspects of number. In an attempt to increase the teachers' comfort level, preparation and understanding of the approaches to number, it is important to design professional development in which teachers are offered active engagements and group collaborations by doing, investigating, sharing, and critiquing artifacts pertaining to the aspects of number. Then, the interactions among digital artifacts, students and teachers can be investigated in the mathematics classroom. 